\title{
PAYING FOR THE “AMERICAN POWER ACT”: AN ECONOMIC AND DISTRIBUTIONAL ANALYSIS OF THE KERRY-LIEBERMAN CAP-AND-TRADE BILL
}

\author{
by \\ Andrew Chamberlain and \\ Feliz M. Ventura \\ Chamberlain Economics Policy Study No. 2010-06 \\ Chamberlain Economics, L.L.C. \\ 9388 Redwood Drive \\ La Jolla, CA 92037
}

June 2010

\begin{abstract}
The "American Power Act" proposed by Sen. John Kerry and Sen. Joseph Lieberman would establish a broad-based U.S. cap-and-trade system. Using an input-output model we estimate the distributional cost of the cap-and-trade portions of the bill to households by income, age group, U.S. region and family type, as well as the value of various industry subsidies granted by the bill. In a typical year (2020), households would face a gross annual burden of $\$ 125.9$ billion per year or $\$ 1,042$ per household, with costs disproportionately borne by low-income households. On a net basis, the large quantity of allowances distributed freely to companies leads households in the top income quintile to benefit financially, redistributing to these households roughly $\$ 12.3$ billion per year from the bottom 80 percent of earners. Overall, we estimate the bill would reduce U.S. employment by roughly 522,000 jobs in 2015, rising to over 5.1 million jobs by 2050 . Finally, we explore two theoretical issues: (1) we offer microeconomic evidence that shareholders rather than households are most likely to benefit from the bill's free allowances to electricity and natural gas utilities; and (2) we show how the bill's exclusion of petroleum refiners from quarterly auctions is likely to increase rather than decrease allowance price volatility, directly contradicting the intent of the legislation.
\end{abstract}

\footnotetext{
* Andrew Chamberlain is chief economist and Feliz M. Ventura is a senior economic consultant at Chamberlain Economics, L.L.C. We wish to thank Mary J. Hutzler, Daniel R. Simmons, and the staff of the Institute for Energy Research for thoughtful comments on earlier drafts. All remaining errors are our own.
} 


\section{TABle of Contents}

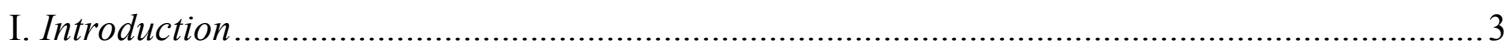

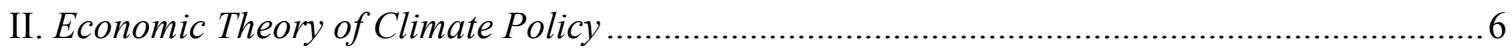

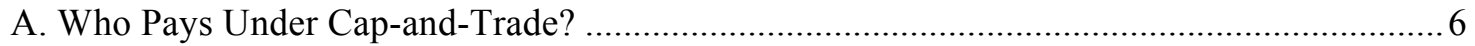

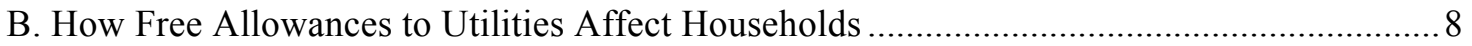

C. Impact of Petroleum Refining Provisions on Price Volatility .......................................... 13

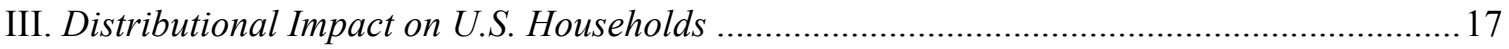

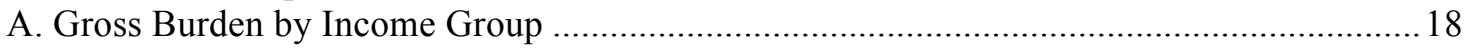

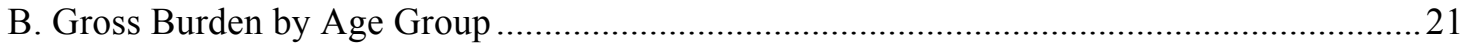

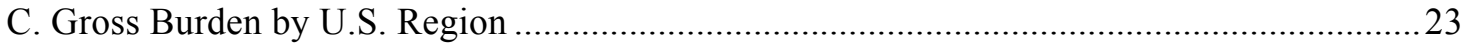

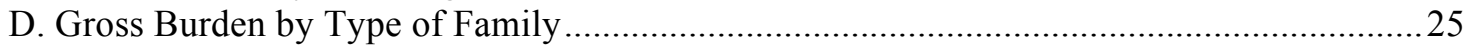

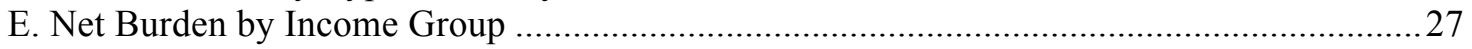

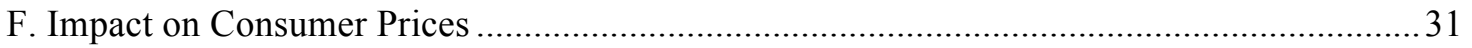

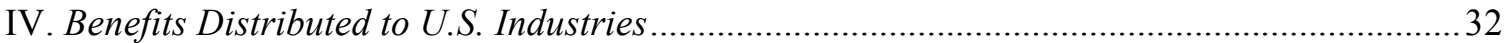

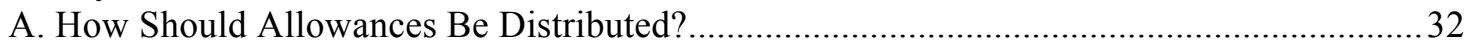

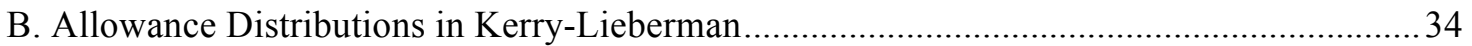

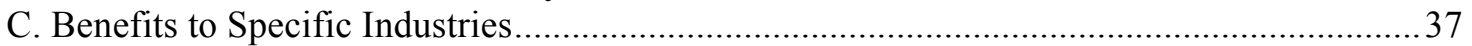

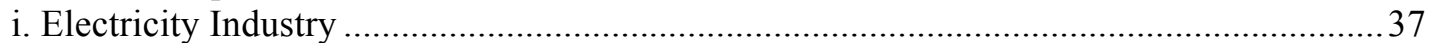

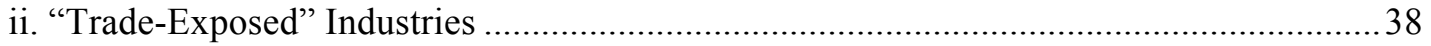

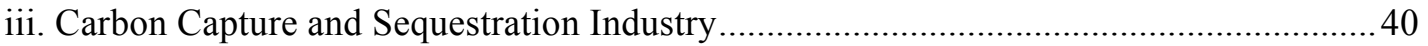

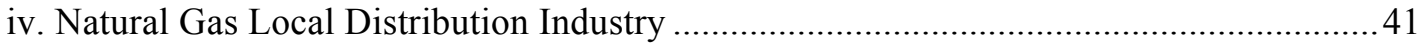

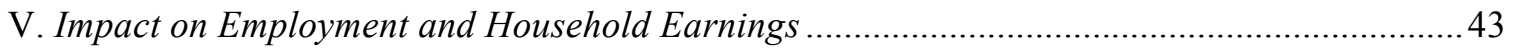

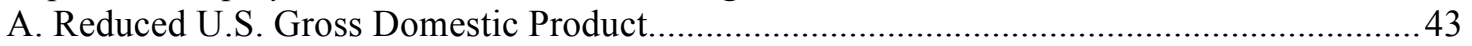

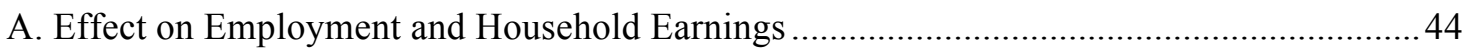

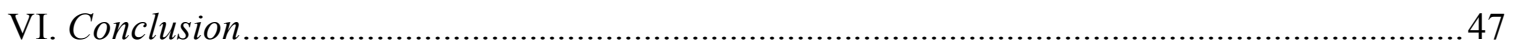

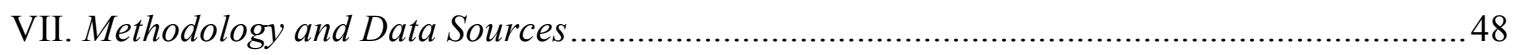

Appendix. Detail on Auction Price Volatility .........................................................................5

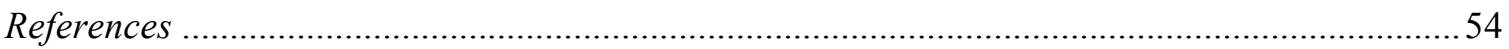




\section{INTRODUCTION}

With the passage of the Waxman-Markey bill in the U.S. House of Representatives last year, lawmakers took a historic step toward establishing a broad-based cap-and-trade system in the United States. ${ }^{1}$ Attention has now turned to the U.S. Senate, where Sen. John Kerry and Sen. Joe Lieberman have unveiled similar legislation known as the "American Power Act" or the "Kerry-Lieberman" cap-and-trade bill.

The Kerry-Lieberman bill would establish a broad-based federal cap-and-trade system, requiring companies in electricity, natural gas, petroleum refining and other industries to hold emission "allowances" or permits for each ton of greenhouse gas emitted. As with the Waxman-Markey bill - and against the advice of economists and policy experts from across the political spectrum - the bill freely distributes most allowances in the first two decades of the program to companies, government agencies and other organizations. The decision to freely distribute allowances has a dramatic effect on how the burdens of the Kerry-Lieberman bill would be distributed among the nation's income groups.

In this study, we explore the Kerry-Lieberman bill's economic impact in detail. In Section II we review the economic theory of climate policy. In Section III we present detailed distributional estimates of the gross and net cost of the bill to households. In Section IV we explore the bill's subsidies to various industries in the form of free allowances to electricity, natural gas, and other firms. In Section V, we explore the bill's likely impact on employment and household earnings. In Section VI we conclude, and Section VII provides background detail on the model used to estimate the distributional impact of the bill on households.

\section{OVERVIEW OF THE LEGISLATION}

A discussion draft of the Kerry-Lieberman bill (the "American Power Act") was released to the public on May 12, 2010 by Sen. John Kerry and Sen. Joseph Lieberman. The bill is one of several recent proposals aiming to curb U.S. greenhouse gas emissions through a broad-based cap-and-trade system. Although the proposal has not yet been formally introduced in the Senate, its 987 pages are already under scrutiny across the nation.

Under the bill, cuts in U.S. greenhouse gas emissions would be achieved by requiring electric utilities, natural gas distributors, industrial operations and petroleum products producers - all of which are known as "covered entities"- to hold allowances equal to their emissions beginning in 2013. These covered entities account for about 85 percent of U.S. emissions. The rules determining which companies are "covered entities" vary by industry, but the bill's authors expect about 7,500 companies to be covered. The number of emission allowances authorized by the bill, known as the "cap," falls from roughly 4.7 billion tons of $\mathrm{CO}_{2}$ in 2013 to 1 billion in 2050, cutting U.S. emissions by 83 percent compared to 2005 levels.

\footnotetext{
${ }^{1}$ See H.R. 2454, “American Clean Energy and Security Act of 2009.”
} 
Companies can either buy allowances at auction or receive them freely from lawmakers. Although most economists and policy experts support full auctioning of allowances, the Kerry-Lieberman bill distributes the vast majority freely to various industries, government agencies and others during the early years of the bill. Between 2013 and 2025 , between 75 and 80 percent of allowances are given away freely each year. Beginning in 2026 the percentage of allowances granted freely begins to decrease, with free allowances disappearing completely in 2035 .

The bill requires electric utilities, natural gas distributors and industrial operations to participate in quarterly auctions to buy any additional allowances they are required to hold beyond those received freely. Unlike the Waxman-Markey bill, a "price collar" is established for allowances - essentially a price control that assures prices do not fluctuate outside of a specified band. In the first year, minimum and maximum allowance prices are set at $\$ 12$ and $\$ 25$, respectively. ${ }^{2}$ These upper and lower bounds are then annually increased by inflation plus 5 percent for the cap and 3 percent for the floor each year.

An unusual feature of the Kerry-Lieberman bill is its exotic treatment of "transportation fuels producers," many of which are petroleum refiners. The bill prevents refiners from participating in quarterly auctions, requiring them instead to buy allowances at auction prices set by bidding among electricity, natural gas and industrial operations. Once refiners have purchased their required allowances, they cannot trade, bank or borrow them-essentially creating a "cap-and-no-trade" system for petroleum refiners. This aspect of the bill is intended to shield refiners from day-to-day price volatility, and is equivalent to imposing a pure carbon tax on refiners. However, as we explain below in Section II, economic theory suggests this system may actually increase price volatility at quarterly auctions for the overall cap-and-trade system.

The revenue generated from auctioned allowances is disbursed in a variety of ways, including: a refund program for low-income consumers; cash subsidies for "tradeexposed" industries; grants for research and development in various industries; expanded funding for road construction programs established by the 2009 "stimulus bill" (the "American Recovery and Reinvestment Act"); grants for various climate change adaptation programs both at home and abroad; and supplementing other federal tax revenue to reduce the federal deficit.

The bill contains a number of other miscellaneous provisions, including removing some authority from the E.P.A. and states to regulate greenhouse gases; an expansion of U.S. offshore oil drilling; funding for increased nuclear power generation; and regulatory systems designed to cut U.S. hydrofluorocarbon and black carbon emissions.

Table 1 summarizes the key provisions of the Kerry-Lieberman bill. In this study, we model only the cap-and-trade provisions. An analysis of the non-cap-and-trade provisions, which may have a large impact on costs, is beyond the scope of this study.

\footnotetext{
${ }^{2}$ The initial 2013 price collar amounts are stated in inflation-adjusted 2009 dollars in the bill.
} 


\section{Table 1. Key Provisions of the Kerry-Lieberman CaP-And-Trade Bill}

(Note: Only CaP-AND-TRade PROVisions are Modeled IN THIS StUdy)

\section{Emission Reductions}

- Regulates industries accounting for 85 percent of U.S. emissions by capping electric utilities, natural gas distributors, petroleum refiners and industrial operations.

- Emissions cap begins in 2013 for electric utilities and petroleum producers, and 2016 for natural gas distributors and industrial operations.

- Cap aims to decrease emissions by 17 percent in 2020, 42 percent in 2030 and 83 percent by 2050 compared to 2005 levels.

- 75.2 percent of allowances are freely allocated in $2013,79.2$ percent in $2020,20.5$ percent in 2030 and 0 percent by 2035 .

\section{Carbon Offsets}

- Covered entities can purchase carbon offsets instead of allowances for part of their obligations; percentage is determined by the entity's share of regulated emissions.

- Mandates the enumeration of eligible domestic offset projects by the EPA and USDA.

- Foreign offsets are also eligible; to be used at a 25 percent discount from domestic offsets.

\section{Nuclear Power}

- Expedited licensing system for qualified new reactors.

- Expands beneficial tax treatment through accelerated deprecation, tax-exempt bonds, investment tax credits and grants in lieu of tax credits.

\section{Offshore Oil and Gas}

- Gives states a 37.5 percent share of revenue from offshore oil and gas activities in some areas; 12.5 percent goes to the Land and Water Conservation Fund for state and federal projects.

- Allows states to prohibit offshore oil and gas activities within 75 miles of the coastline.

\section{Coal}

- Mandates program for commercial deployment of carbon capture and sequestration.

- Establishes performance standards for new coal-fired power plants through 2020.

\section{Renewable Energy}

- Provides loans under the Rural Energy Savings Program for energy efficiency projects using allowance auction revenue.

- Funds renewable energy and energy efficiency programs by states and Indian Nations.

\section{Clean Transportation}

- Authorizes an electric vehicle infrastructure feasibility plan and pilot program.

- Directs states and planning organizations to cut transportation emissions.

- Creates a Clean Energy Technology Fund. 


\section{Economic Theory of Climate Policy}

Economic theory provides a useful framework for understanding how cap-and-trade affects households and the broader U.S. economy. We explore three theoretical issues in this section: (1) how cap-and-trade affects consumer prices; (2) how the KerryLieberman bill's free allowances to electric and natural gas utilities will affect costs to households; and (3) how the bill's exclusion of petroleum refiners from quarterly auctions will affect allowance price volatility.

\section{A. Who Pays Under CaP-And-Trade?}

The basic goal of cap-and-trade is to curb the economy's greenhouse gas emissions. The policy achieves this goal by capping the economy's total emissions and allowing companies to buy "allowances" or permits for each ton of carbon dioxide they emit. In effect, cap-and-trade operates as a per-unit tax on carbon emissions, with the tax equal to the price of an emission allowance. In the language of supply and demand, cap-and-trade shifts the supply curve for carbon-intensive products to the left, forcing up consumer prices for these products.

Figure 1 illustrates the impact of cap-and-trade on consumer prices. Before cap-andtrade, the market for a typical carbon-intensive product - such as electricity, gasoline or fuel oil - is in equilibrium at the intersection of the supply and demand curves, labeled $S_{o}$ and $D$ respectively. At that point, the economy produces $Q_{o}$ of the carbon-intensive good at a price of $P_{o}$.

Figure 1. IMPACt of CAP-AND-TRAde on Consumer Prices

LONG-RUN ECONOMIC IMPACT OF CAP-AND-TRADE

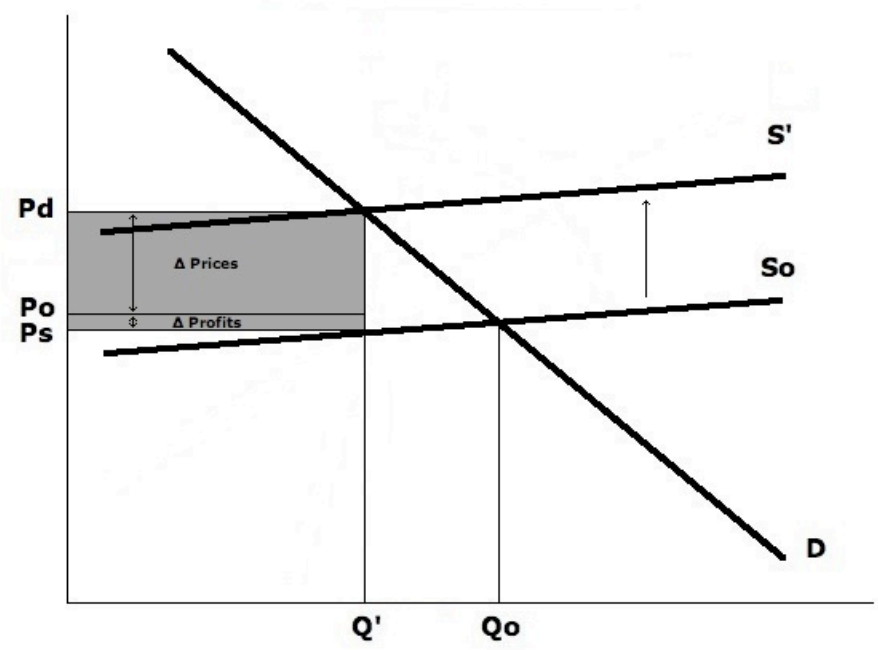

Source: Chamberlain Economics, L.L.C.

Under cap-and-trade, greenhouse gas emissions are "capped" and firms are required to purchase allowances or permits equal to the amount of greenhouse gases they emit. This 
has the effect of shifting the supply curve upward in the figure by the cost of an emission allowance, to the line labeled $S^{\prime}$. Under the policy, the price paid by consumers for the carbon-intensive product rises to $P_{d}$, and the price received by companies falls slightly to $P_{s}$. The gap between the two is the cost of an emission allowance. That is, the total price paid by consumers is equal to the price received by firms plus the cost of the emission allowance the company is required to hold. In this way, cap-and-trade is economically equivalent to a per-unit tax on carbon emissions.

Although companies will bear some portion of cap-and-trade burdens in the short run, in the long run economists agree consumers are left with the entire burden of cap-and-trade. The division of costs between firms and consumers is clear in Figure 1. The portion borne by consumers is illustrated by the large upper portion of the gray-shaded rectangle labeled " $\Delta$ Prices." The small lower portion of the rectangle labeled " $\Delta$ Profits" shows the portion borne by companies. In the long-run, the supply curve in Figure 1 can be thought of as horizontal or "perfectly elastic," with little or no impact on company profits and cap-and-trade burdens borne fully by consumers. ${ }^{3}$

This theoretical framework - that consumers bear the full burden of cap-and-trade in the long run-serves as the basis for the estimates of household burdens from the KerryLieberman bill in Section III of this study.

\footnotetext{
${ }^{3}$ Fullerton (1995), Metcalf (1999) and others refer to this as the "Armington" assumption after Armington (1969). Specifically, it assumes U.S. products are sufficiently different from foreign substitutes to allow the long-run demand curve for domestic products to be downward-sloping, while long-run supply is highly elastic. The result is that long-run cap-and-trade burdens are fully forward-shifted in the form of higher prices, despite the division of burdens between consumers and firms in the short run. See Chamberlain and Ventura (2010), p. 6-10, for a discussion of how the elasticity of supply for carbon-intensive products is likely to grow larger over time under cap-and-trade.
} 


\section{B. How Free Allowances to Utilities Affect Households}

The Kerry-Lieberman bill distributes a large number of free allowances to electricity and natural gas local distribution companies (LDCs). The bill specifies utilities must use these allowances "for the benefit of" ratepayers, fully passing on this subsidy to consumers rather than shareholders.

Several recent analyses have adopted this assumption that the benefit of free LDC allowances will be fully passed forward to consumers, either in the form of lower rates, lump-sum rebates, or some other unspecified method. For example:

- A recent Congressional Budget Office analysis of the Waxman-Markey bill assumed the $\$ 14$ billion subsidy granted to electricity and natural gas LDCs in 2020 would be directly transferred to households. ${ }^{4}$ Despite well-documented lobbying expenditures by LDCs to secure these provisions, the CBO analysis assumes shareholders receive no benefit from free allowances. The authors do not specify a microeconomic justification for this approach, stating that, "[f]or the allowances given to local distributors of electricity or national gas with instructions to pass the benefits on to their residential customers, $\mathrm{CBO}$ assumed that the value of those allowances would be received by those households."

- A December 2009 study from Resources for the Future $^{5}$ estimated the distributional impact of the Waxman-Markey bill, assuming electricity and natural gas LDCs will "act as trustees on behalf of consumers and will use the allowance value to lessen the burden of climate policy." The authors justify this assumption on the grounds that LDCs are regulated entities. However, the study does not consider the possibility of imperfect state and local regulation, or other welldocumented regulatory problems such as strategic cost-inflation by managers, regulatory capture, or other forms of regulatory failure that would invalidate that assumption. ${ }^{6}$ In the case of free allowances granted to LDCs on behalf of industrial and commercial customers, the authors do recognize some uncertainty, noting that, "[i]t is unclear ... whether the benefits will accrue to shareholders or be reflected in lower prices of goods and services for households."

- A June 2010 study from the National Bureau of Economic Research (NBER) ${ }^{7}$ analyzed the distributional impact of the Waxman-Markey bill under the

\footnotetext{
${ }^{4}$ See U.S. Congressional Budget Office, "The Economic Effects of Legislation to Reduce Greenhouse-Gas Emissions.” CBO Publication No. 4001 (September 2009).

${ }^{5}$ See Dallas Burtraw et al., "Distributional Impacts of Carbon Pricing Policies in the Electricity Sector," Resources for the Future Discussion Paper 09-43 (December 2009).

${ }^{6}$ See for example, George J. Stigler, "The Theory of Economic Regulation," The Bell Journal of Economics and Management Science (Spring 1971).

${ }^{7}$ See Sebastian Rausch et al., "Distributional Implications of Alternative U.S. Greenhouse Gas Control Measures,” NBER Working Paper No. 16053 (June 2010).
} 
assumption that regulators can induce utilities to distribute the full value of free LDC allowances to households as lump-sum transfers. The authors do not address why lawmakers would choose to use firms as a financial conduit for these transfers rather than directly rebating funds to households, or why profit-seeking LDCs would expend tremendous resources aggressively lobbying for such provisions in recent years if they provided no benefit to shareholders. ${ }^{8}$ The authors do not specify a microeconomic rationale for this assumption, stating that, "we allocate to households the proposed distribution of allowances to LDCs based on emissions and respective electricity and natural gas consumption."

The assumption that consumers benefit from LDC subsidies has a dramatic impact on the distributional fairness of cap-and-trade. Both the Waxman-Markey and the KerryLieberman bills distribute tens of billions of dollars to utilities each year through free allowances. If these subsidies are assumed to costlessly pass through to consumers - as in each of the above studies - the regressive impact of cap-and-trade largely disappears, as free allowances fully compensate low- and middle-income households for the cost of the policy. If instead shareholders are assumed to benefit, LDC subsidies dramatically worsen the regressive impact of cap-and-trade, channeling net benefits only to upperincome shareholders while leaving low- and middle-income families with the full burden of cap-and-trade. Thus, the question of who benefits from free allowances to LDCs is a central issue in distributional analyses of cap-and-trade proposals.

\section{The Microeconomic Evidence}

Despite the widespread assumption that LDC subsidies will mostly benefit consumers, this view rests on fragile theoretical ground. Lawmakers can specify the statutory or legal incidence of free emission allowances, but they do not control the actual economic incidence. The ultimate beneficiaries of LDC subsidies are not determined by the text of legislation or the intentions of Congress; they are determined by the economic behavior of profit-maximizing firms operating within an imperfect state and local regulatory regime. The potential for divergence between statutory and economic incidence of subsidies to public utilities has a long history in the regulatory literature. ${ }^{9}$

The question of who benefits from LDC subsidies is analytically similar to the tax incidence question of who pays state and local gross receipts taxes. States typically place the statutory incidence of these taxes on businesses, mandating that revenue officialswho represent the regulatory regime enforcing tax provisions-oversee that firms do not in fact forward-shift burdens onto consumers. In practice, economists widely acknowledge that profit-seeking firms routinely forward-shift gross receipts tax burdens, directly contradicting the statutory incidence specified by lawmakers in legislation. ${ }^{10}$

\footnotetext{
${ }^{8}$ See for example, Marianne Lavelle, “The Climate Change Lobby Explosion," The Center for Public Integrity (February 24, 2009).

${ }^{9}$ See for example, U.S. Energy Information Administration, "Federal Financial Interventions and Subsidies in Energy Markets 2007" (2007), in particular page 5 under "The Incidence Theory."

${ }^{10}$ See for example, John L. Mikesell, "Gross Receipts Taxes in State Government Finances: A Review of Their History and Performance,” Tax Foundation Background Paper No. 53 (January 2007).
} 
Similarly, while the text of the Kerry-Lieberman bill places the statutory incidence of LDC subsidies on consumers, there is no guarantee that the economic incidence will follow a similar pattern. In the case of LDCs that are regulated under an "average cost-ofservice" regime - common throughout municipal utility regulation in the U.S. ${ }^{11}$ - there are strong microeconomic reasons to doubt the assumption that ratepayers, rather than utility shareholders, will primarily benefit.

\section{Figure 2. Microeconomic Theory of Free AllowANCES ON AN Average-Cost-OF-SERVICE Price Regulated LDC}

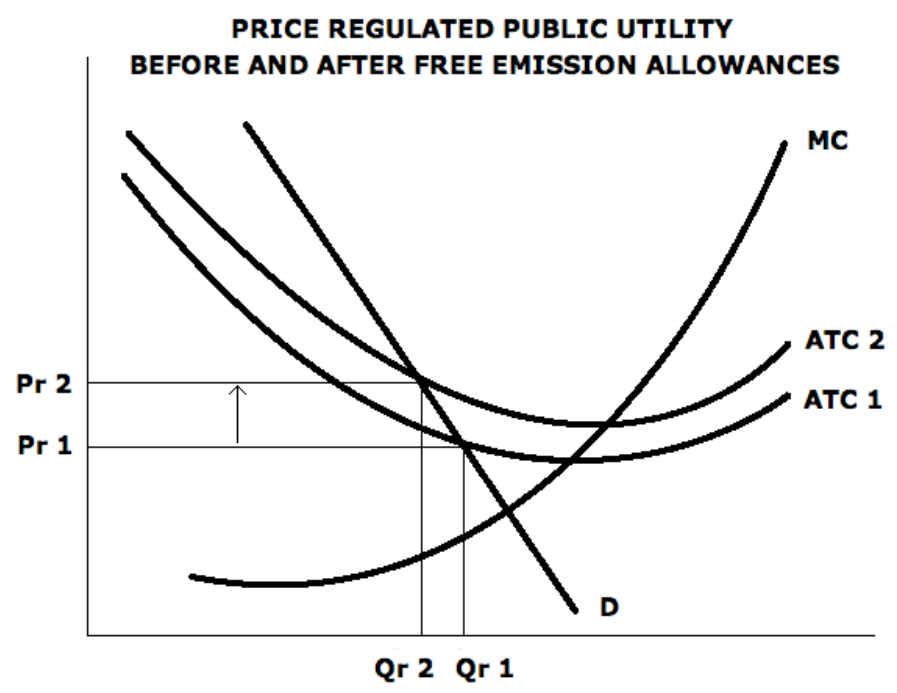

Source: Chamberlain Economics, L.L.C.

Consider a municipal regulator charged with setting electricity rates equal to an LDC's average cost of production under cap-and-trade. Figure 2 illustrates the microeconomic theory of such a regulated monopoly firm. Before cap-and-trade, the firm's average total cost curve is labeled $A T C 1$. Under this cost structure, utility managers will choose to produce $\mathrm{Qr} 1$ units of output, corresponding to the intersection of the average total cost curve and the market demand curve $D$. At this level of output, regulators will set prices equal to average total cost, or $\operatorname{Pr} 1$.

Under cap-and-trade, the LDC's average total cost curve shifts upward to ATC 2. This occurs regardless of whether the utility is required to purchase allowances via auction or are given freely by lawmakers. Under auctioned allowances, the firm's fixed costs rise by the amount of the allowances purchased. Under free allowances, if the firm chooses to hold them rather than sell them on the open market it incurs an opportunity cost equal to the value of the allowances received.

\footnotetext{
${ }^{11}$ See for example, Government Finance Officers Association, "GFOA Recommended Practice: Setting of Government Charges and Fees." (January 2001).
} 
To see why costs rise in either case, imagine a utility has been granted a free allowance with a market value of $\$ 35$. Utility managers can choose to restrict its electricity output enough to reduce emissions by one ton and then sell this allowance for $\$ 35$. To maintain this same level of output, the LDC must sacrifice that potential $\$ 35$; thus, the firm's costs have risen. In either case, the firm's average total cost curve shifts upward.

Following this upward shift in cost structure, a profit-maximizing manager will reduce output to $\operatorname{Qr} 2$. Under an average-cost-of-service pricing rule, regulated utility rates will rise to $\operatorname{Pr} 2$ - even if allowances are distributed freely - shifting the economic incidence of free allowances onto shareholders rather than consumers. Thus, even under a typical regulatory regime there are strong theoretical reasons to believe shareholders stand to benefit from at least some portion of LDC subsidies granted via free allowances.

\section{IMPACT OF IMPERFECT REGULATION}

It is certainly true that if regulators possess perfect knowledge of a utility's true cost structure, as in the idealized diagram in Figure 2, they face no challenge pinpointing their "true" out-of-pocket production costs, excluding the opportunity cost of free allowances. But in the actual regulatory world - a highly decentralized patchwork of state-local regulatory systems facing limited budgets and staff-imperfect regulators are unlikely to be able to distinguish if cost increases submitted as part of a routine rate-adjustment proposal are due to necessary changes in out-of-pocket costs, or simply due to additional opportunity costs from free allowances. As regulatory economist George J. Stigler famously noted, utility managers have many ways to adjust under regulation:

Since accounting costs are hardly unique, there is a real question whether the regulatory body can even distinguish between costs of [different output levels]. Let the commission be given this knowledge; then the utility can reduce costs ... by reducing one or more dimensions of the services which are really part of its output: peak load capacity, constancy of current, promptness of repairs, speed of installation of service. It can also manipulate its average price by suitable changes in the complex rate structure. ${ }^{12}$

Although several recent distributional studies have assumed consumers will enjoy the full benefit of LDC subsidies, there are equally reasonable microeconomic reasons to believe the profit-maximizing behavior of regulated LDCs will instead channel at least some of these benefits to shareholders. If they are successful, the LDC subsidies in the KerryLieberman bill will have precisely the opposite effect of that found in the above studiesdramatically worsening the regressivity of cap-and-trade rather than making the policy more progressive across income groups.

\footnotetext{
${ }^{12}$ George J. Stigler and Claire Friedland, "What Can Regulators Regulate? The Case of Electricity," Journal of Law and Economics (October 1962), p. 11.
} 


\section{Box 1. Why Electricity Rates Rise Even When Allowances Are Free: THE CASE OF THE EU'S EMISSION TRAdING SySTEM}

The Kerry-Lieberman bill would distribute a large number of free allowances to electricity and natural gas distributors with the stipulation that they be used "for the benefit of" ratepayers. However, the experience of the European Union Emissions Trading System (EU ETS) illustrates how utility managers face powerful economic incentives to raise rates even if allowances are distributed freely.

A 2008 New York Times analysis of the E.U. system illustrates the point: even if allowances are granted freely, consumer prices still rise to reflect the underlying scarcity of allowances - a market response regulators are unlikely to be able to stop:

“...Beseeched by giant utilities and smokestack industries that feared for their competitiveness, the European Union scrapped the idea of forcing industries to buy their permits, with the money going to public coffers. Instead, governments gave out the vast majority of the permits for nothing. ...

"After the system kicked off, in 2005, power consumers in Germany started to see their electrical bills increase by 5 percent a year. RWE, the power company, received 30 percent of all the permits given out, more than any other company in Germany.

"The company said its price increases from 2005 to 2007 predominantly reflected higher costs of coal and natural gas. But the company acknowledged charging its customers for the emission permits, saying that while it may have received them free from the government, they still had value in the marketplace. ..."

Source: James Kanter and Jad Mouawad, "Money and Lobbyists Hurt European Efforts to Curb Gases." New York Times. (December 11, 2008). 


\section{Impact of Petroleum Refining Provisions on Price Volatility}

The Kerry-Lieberman bill features an unusual auction procedure for emission allowances. The bill excludes producers of "transportation fuels and refined petroleum products"mostly domestic petroleum refiners - from quarterly allowance auctions, but still requires them to buy allowances equal to their emissions. ${ }^{13}$ In this section and in the accompanying Appendix, we explore what impact this system may have on allowance price volatility under Kerry-Lieberman.

At the start of each quarter, the bill requires regulators at the Environmental Protection Agency (EPA) and the Energy Information Administration (EIA) to forecast how many emission allowances refiners will need for the quarter. These are set aside, and the remaining allowances are sold via auction to electricity, natural gas and other covered entities. At the end of the quarter, refiners buy the allowances set aside for them, paying the price that was set at the auction held earlier in the quarter. Refiners cannot trade, bank or borrow these allowances, effectively imposing a carbon tax on refiners with a quarterly adjusting rate. If regulators set aside too many or too few allowances, the difference is made up next quarter by adjusting the forecast.

This unusual system is designed to shield refiners from day-to-day volatility in allowance prices. Lawmakers' goal is to ensure a single quarterly price for all refiners, preventing them from having to use hedge funds to manage allowance price risk. ${ }^{14}$ However, economic theory helps clarify whether this auction procedure will in fact lead to lower allowance price volatility, at least on a quarterly basis, for petroleum refiners.

\section{ECONOMic Theory of Auctions}

Under an ordinary auction, all covered firms would participate in quarterly auctions. Regulators would face a single downward-sloping demand curve for allowances, representing the overall economy's valuation of the right to emit a ton of greenhouse gas. At auction, regulators would announce the quantity of allowances, and companies would bid until a price is reached that sells all the allowances. Under an ordinary auction procedure, regulators always arrive at the efficient or "correct" allowance price each quarter that sells exactly the number of allowances available and no more.

By contrast, under Kerry-Lieberman regulators are unlikely to arrive at the correct allowance price on the first attempt. To see why, recall that the bill would divide refiners and non-refiners into two groups. Regulators would face two demand curves for allowances: one for refiners and one for non-refiners. Regulators would first set-aside a forecast of allowances needed by refiners, and then auction the remaining to non-refiners. At auction, the allowance price would be determined only by non-refiner demand, as

\footnotetext{
${ }^{13}$ See Sec. 729, "Compliance for Transportation Fuels and Refined Petroleum Products," the "American Power Act."

${ }^{14}$ See Office of Senator John Kerry, “Addressing Transportation and Refined Products,” available at www.kerry.senate.gov/imo/media/doc/transpolpage.pdf.
} 
refiners are excluded. Refiners would then observe this price and choose their output and emissions for the quarter.

Unless regulators by accident forecast exactly the quantity of allowances demanded by refiners - an unlikely event - the number set aside will be somewhat too small or large. Unlike an ordinary auction, the Kerry-Lieberman procedure will therefore result in quarterly allowance prices that are somewhat too high or low compared to the "correct" price that would sell all available allowances at an ordinary auction that allowed all covered entities to bid for them.

Viewed this way, the Kerry-Lieberman auction procedure amounts to a series of quarterly guesses by regulators, which in turn leads to a series of quarterly allowance prices, each somewhat too high or low compared to what would prevail at an ordinary auction. For the Kerry-Lieberman procedure to achieve the goal of reduced price volatility to refiners, this series of quarterly forecasts must therefore become more accurate over time. If instead regulators err by similar amounts each quarter or-even worse-err by larger amounts over time, prices will fail to converge on the correct value, instead swinging erratically from one period to the next.

\section{Three Possible Cases}

In the Appendix we mathematically show that under reasonable assumptions about industry demand and regulators' forecasts, it is unlikely that the Kerry-Lieberman auction procedure will converge toward the correct allowance price over time. Instead, we show there are three possible cases - price convergence, divergence, and oscillation-and estimate which scenario is likely to occur in practice.

The first case is price convergence. In this case, regulators' forecasts errors shrink over time, leading them to make better and better forecasts until the "correct" allowance price is reached. The second case is price divergence. In this case, the system leads regulators to make larger forecast errors over time, snowballing from one quarter to the next and causing extreme price volatility for U.S. industries. The last case is price oscillation, in which regulators err by similar amounts each quarter, causing prices to bounce between too high to too low over time.

Simple economic theory shows which of the three cases will occur in reality. The determining factor is refiners' sensitivity to the price of emission allowances, compared to non-refiners. That is, whether the system will actually decrease price volatility as intended by lawmakers depends on something beyond their control: the relative shapes of the two demand curves for allowances faced by regulators. ${ }^{15}$

If refiners' demand for allowances is less elastic than non-refiners, they will react in a muted way to incorrect forecasts from regulators, leading prices to converge over time. However, if refiners' demand for allowances is instead more elastic, the opposite will

\footnotetext{
${ }^{15}$ See Appendix for further detail. We consider only the case of linear demand functions, which in the case of non-linear demand curves can be considered reasonable approximations.
} 
occur: each incorrect forecast will lead to even larger errors in the future, increasing price volatility. If refiners and non-refiners have identical demand curves for allowances, prices will neither converge nor diverge, instead oscillating from too high to too low over time.

\section{Will Prices Converge or Diverge?}

Using evidence from econometric studies, we can determine which of the above cases is likely to occur under Kerry-Lieberman. If studies find refiners are less price-elastic than non-refiners, allowance prices will converge. If instead studies find that refiners are more price-elastic, prices will diverge or oscillate, increasing volatility over time.

One recent econometric estimate from Bataille and Jaccard (2007) provides evidence to help determine which scenario is most likely. The study estimated the greenhouse gas price elasticity for several Canadian industries that are broadly similar to the U.S. industries that would be covered by Kerry-Lieberman. ${ }^{16}$ Table 2 presents the study's estimates of greenhouse gas price elasticities for refiners and non-refiners.

TAble 2. Estimated Price Elasticities for EMisSion AllowanCeS

\begin{tabular}{lc}
\multicolumn{2}{c}{ FOR PETROLEUM REFINERS VS. NON-REFINERS } \\
\hline Industry & $\begin{array}{c}\text { Greenhouse Gas } \\
\text { Price Elasticity }\end{array}$ \\
\hline Petroleum Refiners & -0.73 \\
& \\
Non-Refiners (Emissions-Weighted Average) & -0.51 \\
Electricity & -0.60 \\
Natural Gas & -0.13 \\
Industrial Sources & -0.46 \\
\hline \hline
\end{tabular}

Source: Bataille and Jaccard (2007).

The price elasticity of greenhouse gas emissions for refiners is approximately -0.73 . By comparison, the elasticities for the three major covered industries that make up nonrefiners are: electricity, -0.60 ; natural gas, -0.13 ; and non-energy industrial sources, -0.46 . Taking an emissions-weighted average of the three, the overall price elasticity for nonrefiners is -0.51 .

These estimates suggest refiners have significantly higher demand elasticity for emission allowances than non-refiners, -0.73 compared to -0.51 . Thus, we conclude the scenario most likely to occur under the bill's auction procedure is price divergence, potentially leading to increased price volatility for petroleum refiners - the opposite of the bill's intention.

The increased price volatility due to the bill's auction procedure can be seen graphically in Figure 3 below. Although we do not provide a detailed explanation of this figure here (please see the Appendix for a detailed explanation and definitions), the basic process of prices becoming more volatile over time due to forecasting error by regulators is visually apparent in the diagram.

\footnotetext{
${ }^{16}$ See Chris Bataille and Mark Jaccard, "Greenhouse Gas and Energy Price Elasticities Using a Hybrid Top-Down, Bottom-Up Model,” draft paper under review (2007).
} 
Figure 3. Price Volatility May Increase Over Time Under the Kerry-Lieberman Bill’s Auction Procedure (SEe ApPENDiX for Detailed Explanation)

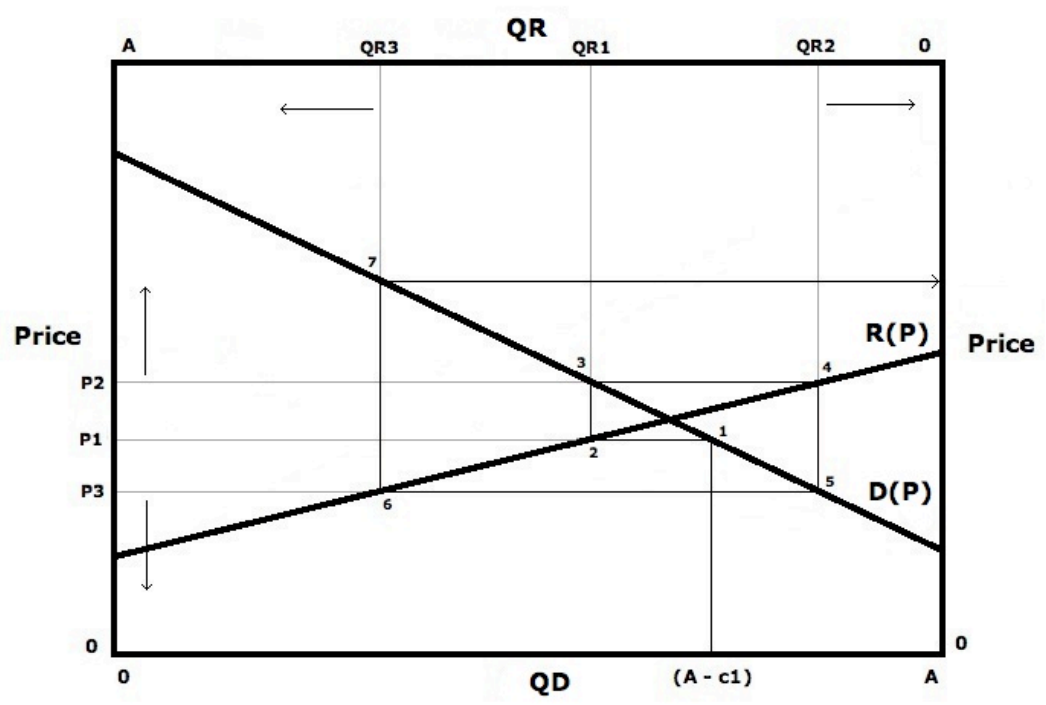

Source: Chamberlain Economics, L.L.C.

In the figure, the points labeled 1 through 7 trace the likely path of allowance prices and quantities over time under the Kerry-Lieberman bill. As the system moves from point to point, the horizontal lines between points represent swings in regulators' forecast errors from one period to the next. The vertical lines between points represent swings in allowance prices from one quarterly auction to the next. As the system spirals outward from point 1, regulators' forecast errors compound each other, causing prices to swing more widely. As explained above, this outward spiraling is determined entirely by the relative slopes of refiner and non-refiner demands for allowances, which are labeled $R(P)$ and $D(P)$ in the figure.

Contrary to the legislation's goal of reducing price volatility by excluding petroleum refiners from quarterly auctions, the Kerry-Lieberman bill is likely to significantly increase allowance price volatility from quarter to quarter, compared to an ordinary auction in which all covered industries bid for allowances. In practice, the allowance price collar established by the bill will help constrain these price swings to some extent. But from the standpoint of ideal policy design the bill's auction procedure is fundamentally unsound-increasing allowance price risk to all covered industries with potentially no offsetting economic or environmental benefit - and should be corrected by lawmakers weighing the legislation. 


\section{DisTRIBUTIONAL IMPACT ON U.S. HOUSEHOLDS}

Economists agree that the cost of cap-and-trade is ultimately borne by households in the form of higher consumer prices in the long run. In this section we provide estimates of the distributional impact of the Kerry-Lieberman bill on U.S. households, presenting annual costs by income groups, age groups, U.S. regions and family types using a standard input-output model of the economy.

Table 3 shows the basic modeling assumptions of the study. We model only the cap-andtrade provisions of the bill - an analysis of the non-cap-and-trade provisions is beyond the scope of this study. We estimate the household impact of the bill in 2020-a typical year in which the system will have been in place seven years with most provisions fully phased in. All figures are presented in inflation-adjusted 2008 dollars, the latest year the income and consumption data used in our analysis are available. The quantity of allowances - roughly 5 billion-is drawn from the text of the bill, and the estimated allowance price of $\$ 32$ per ton is based on a mid-point of the upper and lower price boundaries established by the bill in that year. ${ }^{17}$

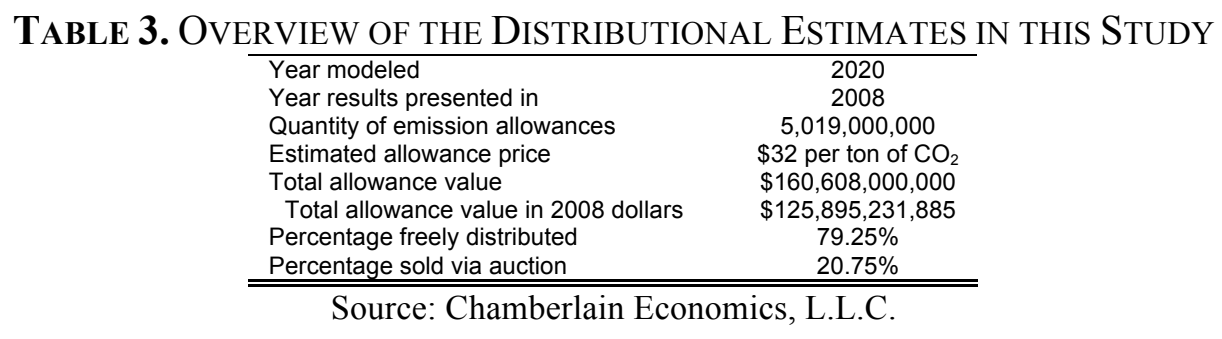

We present estimates of both the "gross" and "net" burden of the bill to U.S. households. The "gross" burden represents the cost to households from higher prices caused by capand-trade. By contrast, the "net" burden represents the gross cost of cap-and-trade minus any government benefits given back to households by the bill—including cash rebates or increased stock returns caused by the bill's distribution of free allowances to companies.

The gross burden estimates are based on Chamberlain Economics, L.L.C.'s input-output model of the U.S. economy, which simulates the bill's impact on prices for goods produced by 134 industries, tracing those price increases to households using data on consumer spending. The model produces estimates of gross burdens by income group, age group, U.S. region, and type of family for calendar year 2008. The "net" burden estimates are then developed by starting with gross burden estimates, and subtracting from them the value of any provisions in the bill that return benefits to households. ${ }^{18}$

\footnotetext{
${ }^{17}$ Section 726(b) and Section 790(d) establish the bill's "price collar." In 2013, the minimum and maximum allowance price is set at $\$ 12$ and $\$ 25$. These figures are annually increased by the rate of inflation plus 5 percent for the cap and 3 percent for the floor. We use the mid-point of the upper and lower price boundaries in 2020 as the forecasted allowance price.

${ }^{18}$ See Section VII for an overview of the input-output methodology and a list of incidence assumptions for the various provisions modeled for the "net burden" estimates.
} 


\section{A. Gross Burden by InCome Group}

A well-known aspect of cap-and-trade is that the price increases it causes inevitably impose a disproportionate burden on low-income families. The reason is simple: lowerincome households typically spend the largest fraction of income on basic products like gasoline, electricity and natural gas-products that are highly carbon-intensive. The result is that the heaviest gross burdens tend to fall on households least able to bear them.

In total, Kerry-Lieberman would impose a gross burden of roughly $\$ 160.6$ billion in 2020. Expressed in 2008 dollars, that amounts to a burden of $\$ 125.9$ billion, for an average of $\$ 1,042$ per U.S. household. Table 4 presents estimates of the annual gross burden from the bill by cash income quintile. Each quintile contains an equal number of households, and all figures are for calendar year $2008 .^{19}$

TABLE 4. GROSS ANNUAL BURDEN FROM KERRY-LIEBERMAN BY INCOME QUINTILE (2008 DOLLARS)

\begin{tabular}{|c|c|c|c|c|c|c|}
\hline & \multirow[b]{2}{*}{$\begin{array}{c}\text { All } \\
\text { Households }\end{array}$} & \multicolumn{5}{|c|}{ Quintiles of Household Cash Income } \\
\hline & & $\begin{array}{c}\text { Lowest } 20 \\
\text { Percent }\end{array}$ & $\begin{array}{c}\text { Second } 20 \\
\text { Percent }\end{array}$ & $\begin{array}{l}\text { Third } 20 \\
\text { Percent }\end{array}$ & $\begin{array}{l}\text { Fourth } 20 \\
\text { Percent }\end{array}$ & $\begin{array}{c}\text { Highest } 20 \\
\text { Percent }\end{array}$ \\
\hline Lower Bound of Household Income & n.a. & n.a. & $\$ 19,065$ & $\$ 36,271$ & $\$ 59,087$ & $\$ 93,358$ \\
\hline Annual Household Burden & $\$ 1,042$ & $\$ 536$ & $\$ 754$ & $\$ 952$ & $\$ 1,206$ & $\$ 1,764$ \\
\hline Household Burden as a \% of Income & $1.6 \%$ & $5.2 \%$ & $2.7 \%$ & $2.0 \%$ & $1.6 \%$ & $1.1 \%$ \\
\hline Aggregate Burden ( $\$$ billion) & $\$ 125.9$ & $\$ 12.9$ & $\$ 18.2$ & $\$ 23.0$ & $\$ 29.1$ & $\$ 42.6$ \\
\hline
\end{tabular}

Source: Chamberlain Economics, L.L.C. Input-Output Model; U.S. Bureau of Labor Statistics'

"Consumer Expenditure Survey"

As with most cap-and-trade systems, middle- and upper-income groups bear the largest dollar burden from Kerry-Lieberman, while lower-income groups bear the heaviest burden as a percentage of household income. Households earning over \$93,358 in cash income fall into the highest-earning quintile, and would bear an annual burden of $\$ 1,764$ per year or 1.1 percent of income. Households in the middle quintile earning between $\$ 36,271$ and $\$ 59,087$ would pay an annual burden of $\$ 952$ or 2 percent of income. And households in lowest-earning quintile earning below $\$ 19,065$ would pay $\$ 536$ per year or 5.2 percent of income.

Figures 4 and 5 present the figures from Table 4 graphically. Figure 4 shows the gross annual burden from Kerry-Lieberman by income quintile, and Figure 5 presents gross burdens as a percentage of household income. As expected, households with higher income and consumption bear a larger dollar burden. However, as a percentage of income, the lowest-earning households would shoulder the heaviest burden. For household costs to the lowest income quintile to equal the same percentage of income as households in the highest quintile (1.1 percent), their dollar burden would have to be reduced from $\$ 536$ per year to just $\$ 114$ per year.

\footnotetext{
${ }^{19}$ The household income concept used throughout this study is "cash income before taxes" as defined by the U.S. Bureau of Labor Statistics' Consumer Expenditure Survey (CEX). It consists of wages and salaries; self-employment income; Social Security, private and government retirement; interest, dividends, rental income, and other property income; unemployment, workers' compensation and veteran's benefits; public assistance, supplemental security income, and food stamps; alimony and child support; and other cash income including scholarships, and stipends. See www.bls.gov/bls/glossary.htm.
} 


\section{Figure 4. ANNUAL Gross BURDEN From KERRY-LIEBERMAN} BY INCOME QuinTILE (2008 DolLARS)

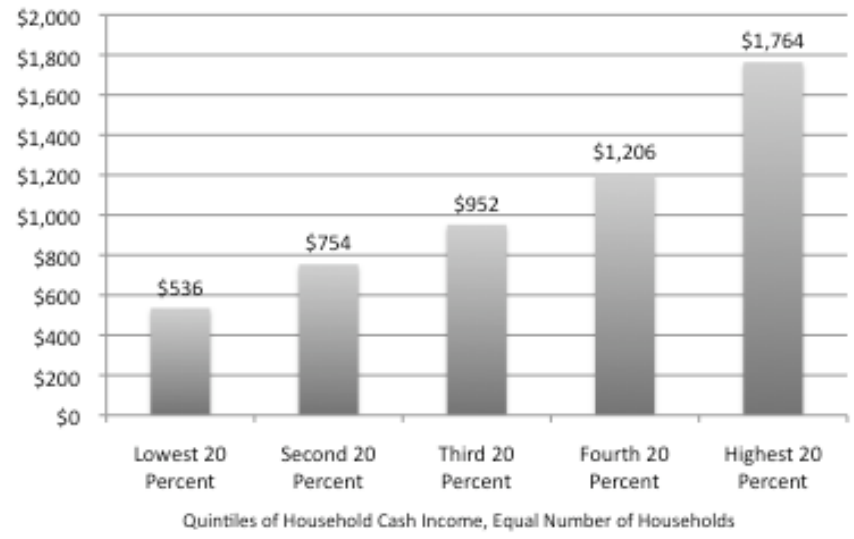

Source: Chamberlain Economics, L.L.C. Input-Output Model

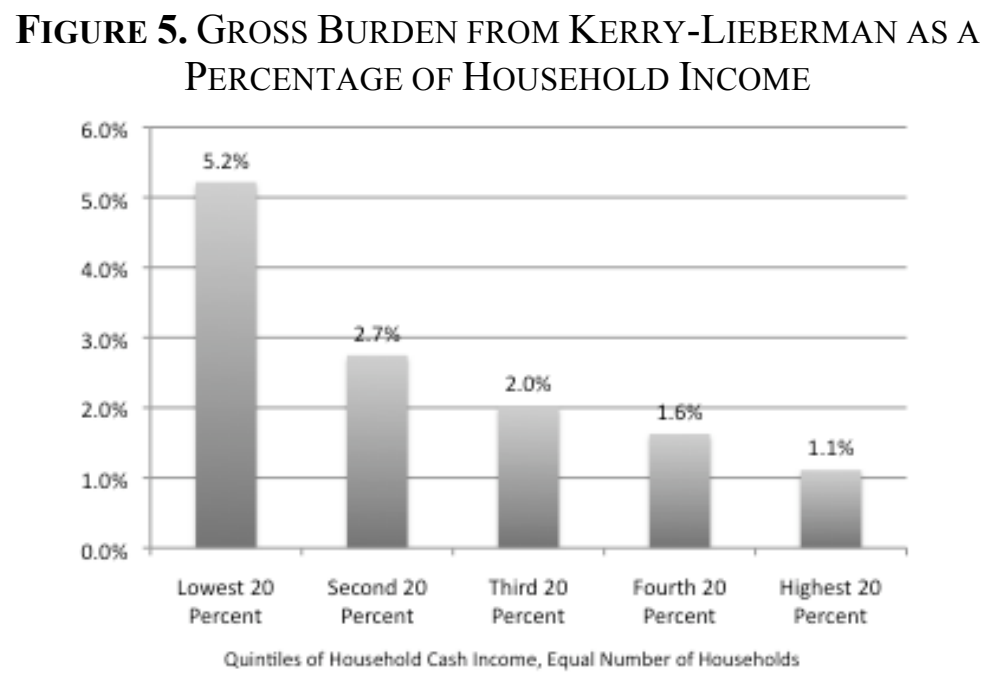

Source: Chamberlain Economics, L.L.C. Input-Output Model

\section{DOLLAR INCOME GROUPS}

One limitation of presenting cap-and-trade burdens by quintile is that it conceals large differences between households within the same quintile. Figures 6 and 7 present a more detailed view of gross burdens for twelve dollar-income groups. ${ }^{20}$

The figures highlight sharp differences in gross burden even within income quintiles. Annual burdens in the highest income quintile alone range from $\$ 1,489$ for those earning between $\$ 100,000$ and $\$ 120,000$ per year to more than $\$ 2,128$ for those earning $\$ 150,000$ per year or more. Figure 7 further emphasizes the regressive nature of cap-and-trade burdens. The bill is estimated to consume about 5.8 percent of cash income for

\footnotetext{
${ }^{20}$ Due to significant under-reporting of income among low-income households, we do not present results for households reporting cash incomes of less than $\$ 5,000$ per year.
} 
households earning between $\$ 5,000$ and $\$ 10,000$ per year, while consuming just 0.9 percent of income for those earning over $\$ 150,000$ per year.

\section{Figure 6. ANNUAL GROSS BURDEN FROM KERRY-LIEBERMAN BY} HouseHold CASH INCOME GROUP (2008 Dollars)

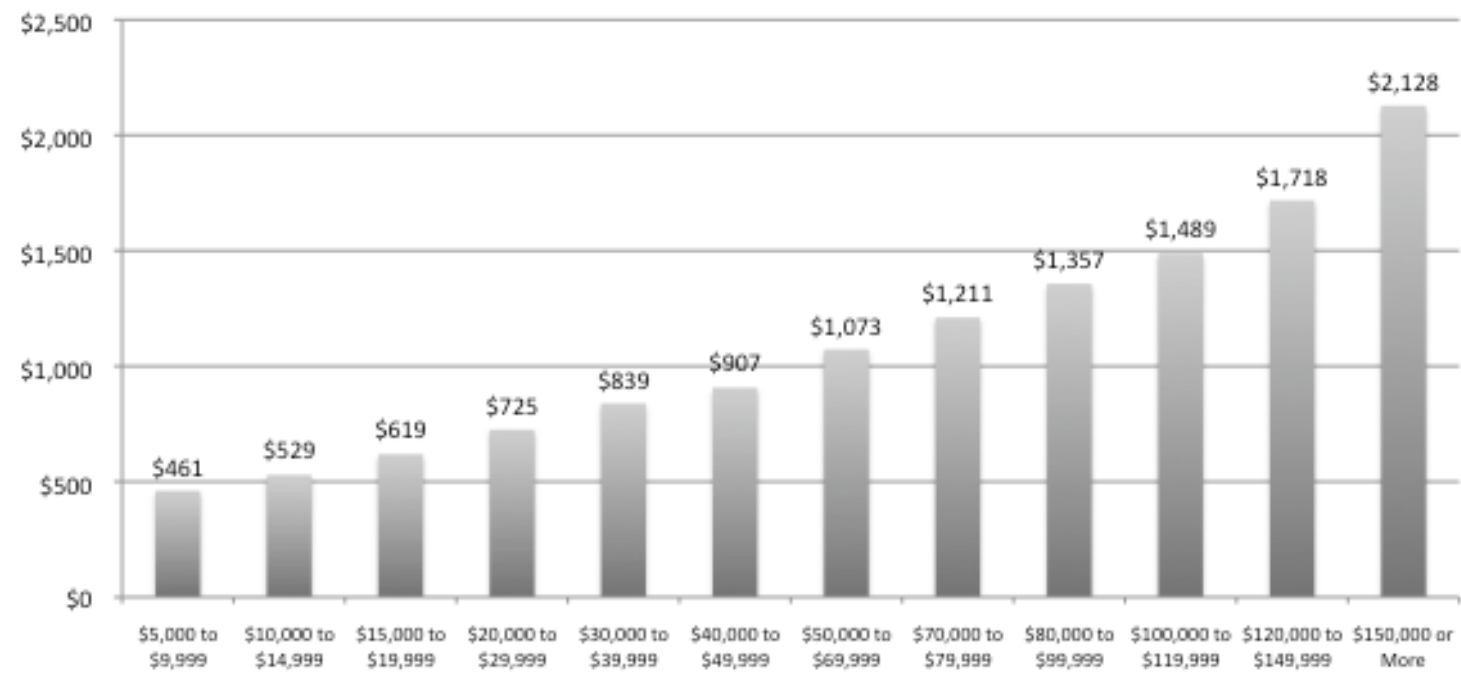

Source: Chamberlain Economics, L.L.C. Input-Output Model

Figure 7. GROSS BURDEN FROM KERRY-LIEBERMAN AS A PERCENTAGE OF HouseHold INCOME

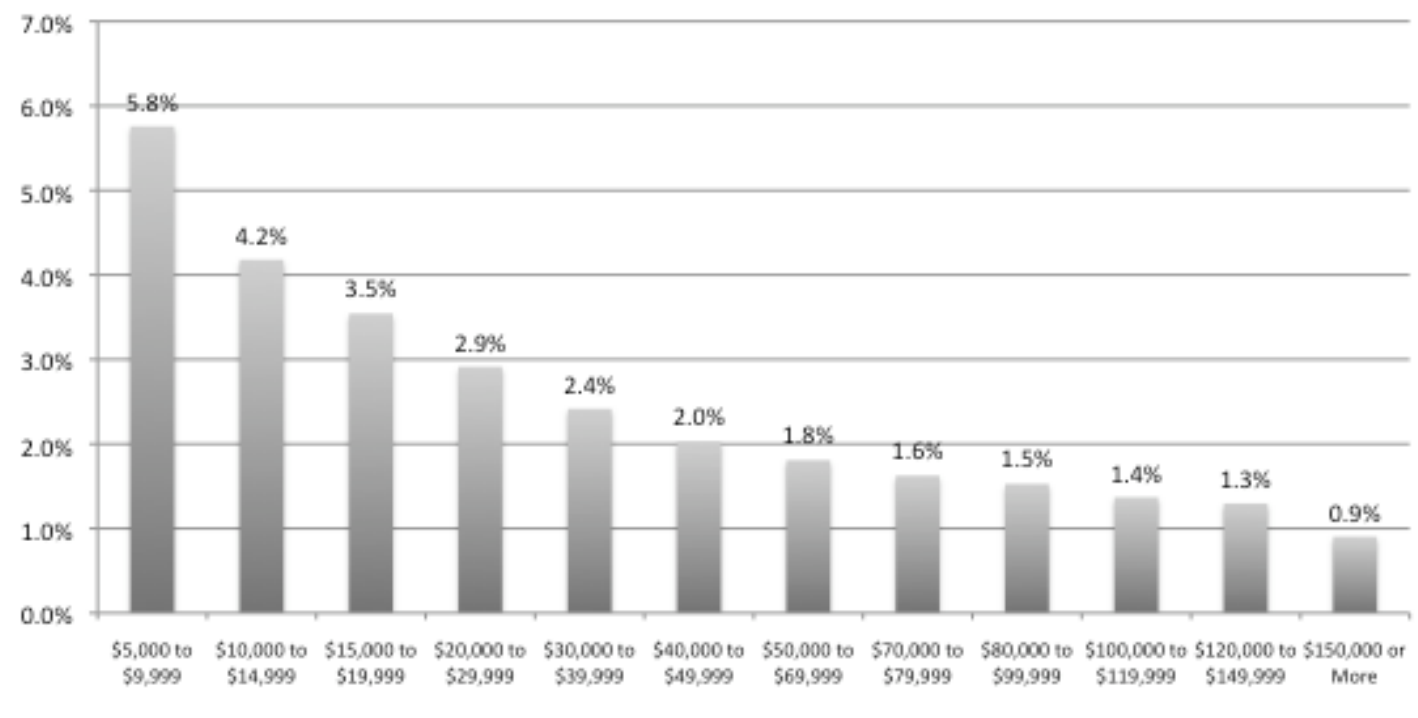

Source: Chamberlain Economics, L.L.C. Input-Output Model 


\section{B. Gross Burden by Age Group}

An often-overlooked aspect of climate policy is how the burdens of cap-and-trade would affect Americans in different age groups. As households move from youth into working years and ultimately into retirement, income and consumption change along with their lifestyles. These differences in consumption patterns lead to sharp differences in cap-andtrade burdens among young, middle-aged and elderly households.

Table 5 shows the distribution of gross burdens from the Kerry-Lieberman by age group. Overall, the smallest dollar burdens are borne by the households at the extremes of the age distribution, while the largest dollar burdens are borne by middle-aged households in their peak earning years. Households under 25 years would bear a burden of just $\$ 604$ per year. Burdens rise sharply for households between 45 and 54 years, who would pay $\$ 1,220$ per year. Burdens again decline for retired households aged 75 and older to just $\$ 763$.

Table 5. Annual Gross Burden from the Kerry-Lieberman Bill by Age Group

\begin{tabular}{|c|c|c|c|c|c|c|c|c|}
\hline & \multirow[b]{2}{*}{$\begin{array}{c}\text { All } \\
\text { Households }\end{array}$} & \multicolumn{7}{|c|}{ Age of Household Head } \\
\hline & & $\begin{array}{c}\text { Under } 25 \\
\text { Years }\end{array}$ & $\begin{array}{l}25-34 \\
\text { Years }\end{array}$ & $\begin{array}{l}35-44 \\
\text { Years }\end{array}$ & $\begin{array}{l}45-54 \\
\text { Years }\end{array}$ & $\begin{array}{l}55-64 \\
\text { Years }\end{array}$ & $\begin{array}{l}65-74 \\
\text { Years }\end{array}$ & $\begin{array}{l}75 \text { Years } \\
\text { and Older }\end{array}$ \\
\hline Annual Household Burden & $\$ 1,042$ & $\$ 604$ & $\$ 932$ & $\$ 1,166$ & $\$ 1,220$ & $\$ 1,178$ & $\$ 962$ & $\$ 763$ \\
\hline Aggregate Burden ( $\$$ billions) & $\$ 125.9$ & $\$ 5.0$ & $\$ 18.8$ & $\$ 26.6$ & $\$ 31.2$ & $\$ 23.4$ & $\$ 12.1$ & $\$ 8.8$ \\
\hline
\end{tabular}

Source: Chamberlain Economics, L.L.C. Input-Output Model

As a percentage of income, the costs of Kerry-Lieberman by age group mirror the bill's regressive impact. In youth and retirement when incomes are lowest, cap-and-trade imposes the heaviest percentage burden. Households over age $75-$ most of whom face relatively fixed incomes and have limited flexibility to adjust to climate policy-bear the largest burden at 2.3 percent of income, followed by households aged 65-74 and under age 25 at 2.1 percent. By contrast, the nation's highest-earning households between age 45 and 54 years would bear the smallest percentage burden of just 1.5 percent.

Figures 8 and 9 present the figures from Table 5 graphically. Figure 8 shows the annual dollar burden of Kerry-Lieberman by age group, and Figure 9 presents household burdens as a percentage of income. As discussed above, the figures are essentially mirror images. Households pay lower dollar burdens and higher burdens as a percentage of income in youth and retirement, and pay large dollar burdens and low burdens as a percentage of income from age 35 to 64 during their prime working years. 
Figure 8. Annual Household Burden from the Kerry-Lieberman Bill by AGE of HouseHold HeAd

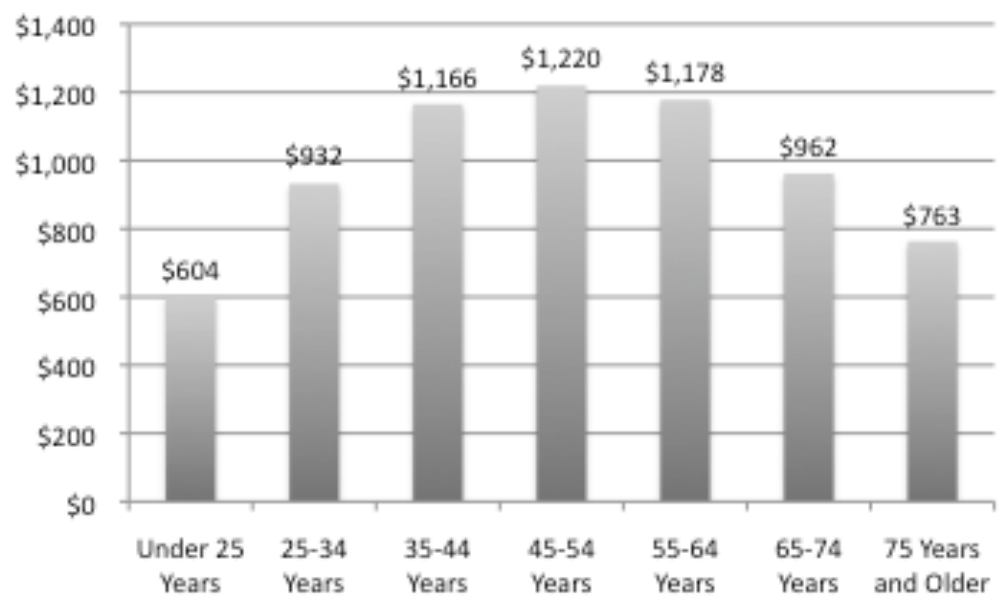

Source: Chamberlain Economics, L.L.C. Input-Output Model

Figure 9. Annual Kerry-Lieberman Burden as a Percentage of HOUSEHOLD INCOME BY AGE GROUP

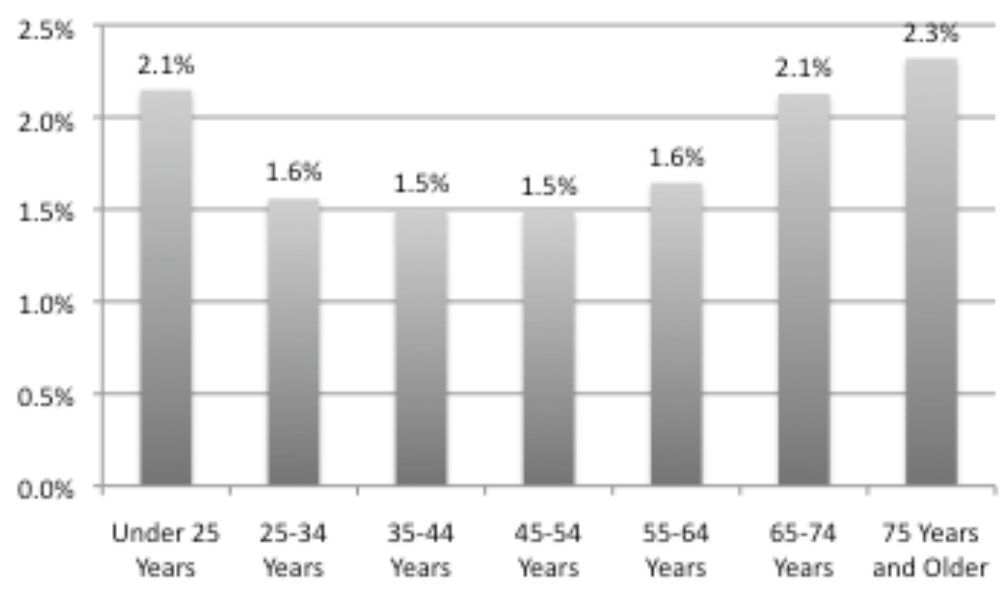

Source: Chamberlain Economics, L.L.C. Input-Output Model 


\section{Gross Burden by U.S. REgion}

As with many federal policies, the gross burden of Kerry-Lieberman would not fall equally on the nation's geographic regions. Sharp differences in income and consumption patterns throughout the nation lead cap-and-trade burdens to fall more heavily on some areas than others. In this section we estimate the burden of the Kerry-Lieberman bill by U.S. region.

The main factor driving cap-and-trade burdens is consumption of carbon-heavy products. For example, in 2008 households in the South spent on average 23 percent more on gasoline and motor oil than households in the Northeast, and roughly 43 percent more on electricity than households in the West-both carbon-intensive products-despite much lower average incomes. These differences in spending patterns help drive geographic differences in the gross cost of Kerry-Lieberman.

Table 6 shows the distribution of gross burdens from Kerry-Lieberman by region. ${ }^{21}$ Overall, the results are more tightly clustered around the national average than burdens by income or age group, largely the result having compiled the nation's roughly 121 million households into just four regional categories. However, regional differences are still apparent even from this highly aggregated view.

\section{Table 6. Annual Gross Burden from the KerRy-Lieberman BiLl by U.S. Region}

\begin{tabular}{lccccc}
\hline & \multicolumn{5}{c}{ U.S. Region } \\
\cline { 2 - 6 } & $\begin{array}{c}\text { All } \\
\text { Households }\end{array}$ & Northeast & Midwest & South & West \\
\hline Annual Household Burden & $\$ 1,042$ & $\$ 1,174$ & $\$ 1,003$ & $\$ 987$ & $\$ 1,064$ \\
Household Burden as a \% of Income & $1.64 \%$ & $1.67 \%$ & $1.64 \%$ & $1.68 \%$ & $1.56 \%$ \\
Aggregate Burden (\$ billions) & $\$ 125.9$ & $\$ 26.2$ & $\$ 27.9$ & $\$ 43.1$ & $\$ 28.7$ \\
\hline \hline
\end{tabular}

Source: Chamberlain Economics, L.L.C. Input-Output Model

In dollar terms, Northeastern households - a region dominated by the State of New York- bear the largest annual gross burden of \$1,174 per year. Southern households face the smallest annual dollar burden at $\$ 987$. In terms of burdens as a percentage of income, households in the Northeast, Midwest and South face very similar burdens. Southern households bear the heaviest burden at 1.68 percent of income. Western households that on average enjoy incomes well above the national average bear the lowest burdens as a percentage of income at 1.56 percent.

\footnotetext{
${ }^{21}$ The regional categories are from the U.S. Bureau of Labor Statistics' Consumer Expenditure Survey (CEX). "Midwest" includes Illinois, Indiana, Iowa, Kansas, Michigan, Minnesota, Missouri, Nebraska, North Dakota, Ohio, South Dakota, and Wisconsin; "Northeast" includes Connecticut, Maine, Massachusetts, New Hampshire, New Jersey, New York, Pennsylvania, Rhode Island, and Vermont; "South" includes Alabama, Arkansas, Delaware, District of Columbia, Florida, Georgia, Kentucky, Louisiana, Maryland, Mississippi, North Carolina, Oklahoma, South Carolina, Tennessee, Texas, Virginia, and West Virginia; and "West" includes Alaska, Arizona, California, Colorado, Hawaii, Idaho, Montana, Nevada, New Mexico, Oregon, Utah, Washington, and Wyoming.
} 
Figures 10 and 11 present the figures from Table 6 graphically. Even at this broad regional level the regressive nature of gross cap-and-trade burdens is apparent. The heaviest burdens as a percentage of income are borne by relatively low-income Southern households, while relatively upper-income Western households bear the smallest relative burden. $^{22}$

Figure 10. ANNUAL HouSEHOLD BURDEN FROM THE KERRY-LIEBERMAN BILL BY U.S. REGION

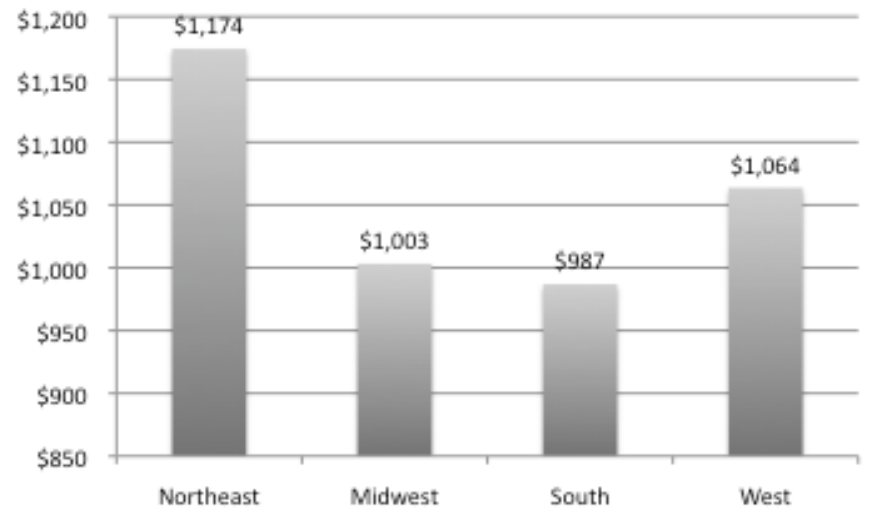

Source: Chamberlain Economics, L.L.C. Input-Output Model

Figure 11. Annual Kerry-Lieberman Burden as a Percentage OF HOUSEHOLD INCOME BY U.S. REGION

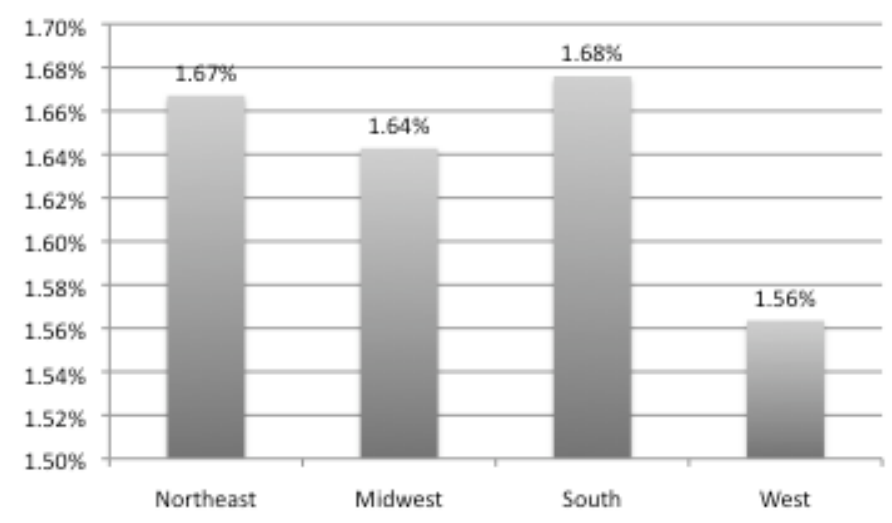

Source: Chamberlain Economics, L.L.C. Input-Output Model

\footnotetext{
${ }^{22}$ In addition to the burdens from higher consumer prices measured here, it should be noted that cap-andtrade policies such as the Kerry-Lieberman bill also impose potentially large short-term adjustment costs to workers and companies in carbon-intensive industries, many of whom are concentrated in particular states and regions. These factors, if added to the household burdens above, would tend to amplify the regional differences in the cost of Kerry-Lieberman presented in Figures 10 and 11.
} 


\section{Gross Burden by Type OF FAMily}

A basic demographic fact is that household income and consumption in the United States are tightly correlated with other family characteristics such as marital status and the presence of children. As a result, an unanticipated side effect of cap-and-trade is that it would impose a disproportionate gross burden on some types of families over others.

On average, the nation's highest-earning households are married couples with children aged 18 years or older. The average age for these head-of-households is 52 years, placing them squarely in the peak earning years for most families. In 2008 these households earned an average income of roughly $\$ 97,700$ per year, 54 percent higher than the national average.

By contrast, the nation's lowest-earning households are typically single parents with at least one child aged 18 years or less. The average age for these head-of-households is just 39 , a full decade younger than the national average. These households earned an average cash income of $\$ 37,100$ in 2008 , just 58 percent of the nation's average.

These patterns in household income are clear in Table 7, which presents estimates of the annual gross burden of Kerry-Lieberman for various types of families. There are significant differences in burdens by family type - a finding that is mostly explained by existing differences in income and consumption of electricity, gasoline, and other carbonheavy products.

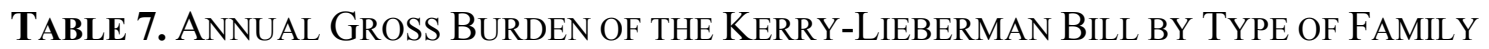

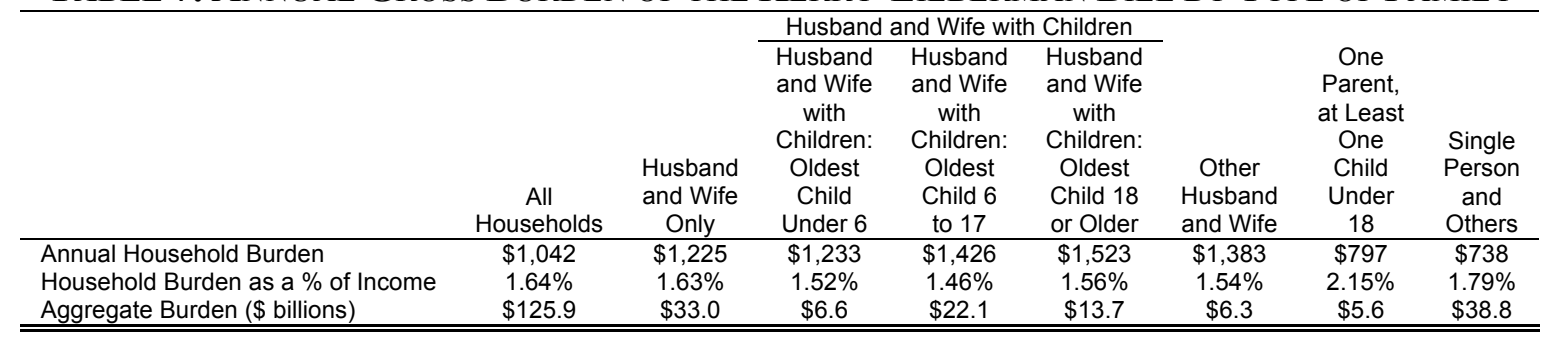

Source: Chamberlain Economics, L.L.C. Input-Output Model

The bill would impose the greatest dollar burden on the highest-earning and highestconsuming household type: married couples with at least one child aged 18 or older. These households would bear a burden of $\$ 1,523$ per year. The smallest dollar burdens fall on single households with no children at $\$ 738$ per year, closely followed by single parents with at least one child under age 18 at $\$ 797$ per year.

When burdens are expressed as a percentage of income, the Kerry-Lieberman bill would impose the highest burden on single parents with young children. These families bear a burden equal to 2.15 percent of income. Married couples with children between age 6 and age 17 pay just 1.46 percent of income, the lightest burden as a percentage of income.

Figures 12 and 13 present the figures from Table 7 graphically. The figures highlight a theme that runs throughout this study: the gross burden of the Kerry-Lieberman bill 
would represent a significant annual cost to most households, with burdens typically falling most heavily on families with relatively low cash incomes.

Figure 12. AnNual Household Burden From the KerRy-LieBERMan BiLl BY TYPE OF FAMILY

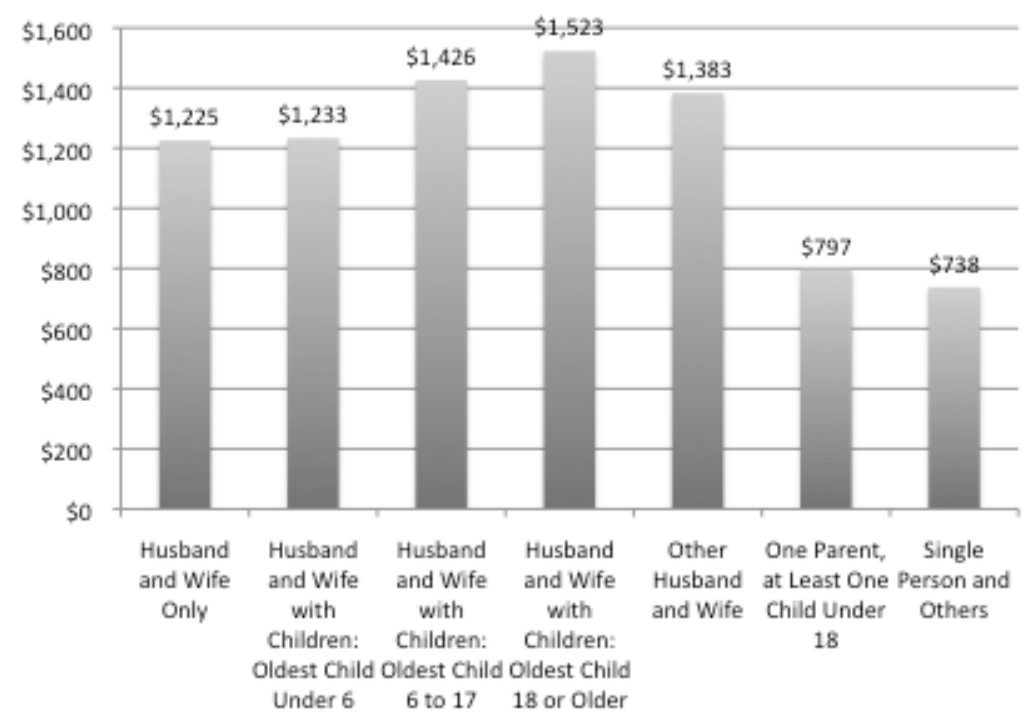

Source: Chamberlain Economics, L.L.C. Input-Output Model

Figure 13. Annual Kerry-Lieberman Burden as a Percentage of HOUSEHOLD INCOME BY TYPE OF FAMILY

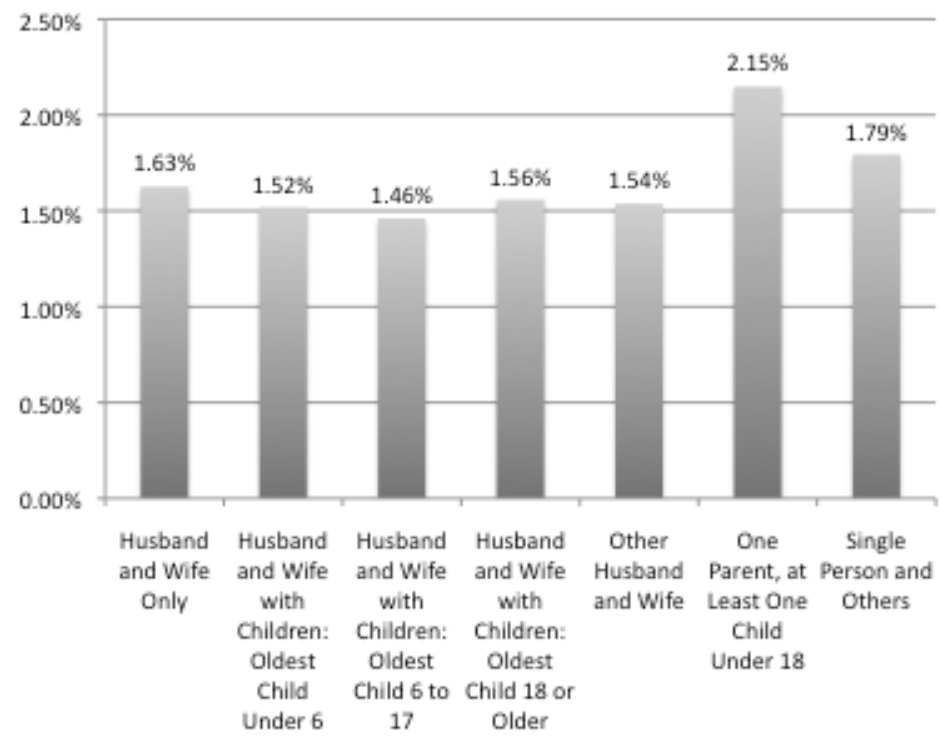

Source: Chamberlain Economics, L.L.C. Input-Output Model. 


\section{E. NET BURDEN BY INCOME GrouP}

In addition to imposing gross burdens in the form of higher consumer prices, KerryLieberman also distributes benefits to households. For example, the bill specifies that 12.3 percent of emission allowances in the early years of the program be auctioned with the proceeds going to low-income households. Similarly, many of the bill's allowances are granted directly to firms, which indirectly provide benefits to households that own shares of stock in those companies.

In this section we estimate the "net" household burden from the Kerry-Lieberman bill. That is, we begin with the gross burdens presented above, subtracting from them any benefits distributed to households by the bill. Consistent with the estimates of gross burdens above, we model the net impact of Kerry-Lieberman in the year 2020, and all figures are presented in 2008 dollars.

In 2020, the Kerry-Lieberman bill distributes the majority of emission allowances freely to various industries, state and local government agencies and other organizations. Of the remaining allowances that are auctioned, the bill distributes auction revenue to various alternative energy programs, low-income households, and others.

In some cases, households would receive direct benefits. For example, the KerryLieberman bill establishes a federal program to distribute rebates to home heating oil and propane consumers, which directly benefits those households. In other cases, households would benefit indirectly. For example, the bill distributes free allowances to firms classified as "trade exposed," which indirectly benefits households that are shareholders of those firms. In other cases, households would not benefit in any identifiable way from allowance distributions. For example, the bill establishes a program for "international climate change adaptation" that distributes free allowances to organizations that may reside outside the United States, not benefiting domestic households in any obvious way.

As discussed in Section II, we do not adopt the view that the economic incidence of free allowances to electricity and natural gas LDCs will necessarily accrue to consumers, as specified by the text of the bill. Instead, we follow the incidence suggested by the microeconomics of regulated monopoly firms discussed above - that utility shareholders will be the ultimate economic beneficiary of LDC subsidies. As with other subsidies to firms in the bill, we distribute the value of free allowances to electricity and natural gas LDCs to households on the basis of reported capital income.

Table 8 provides a list of allowance distributions in the Kerry-Lieberman bill we estimate will return benefits to households in 2020, along with the per-household benefit by income $_{\text {quintile. }}{ }^{23}$ Most provisions primarily benefit shareholders throughout the economy, as they provide free allowances to firms in electricity, natural gas local distribution, clean vehicle production, petroleum refining and other industries. The value

\footnotetext{
${ }^{23}$ For a complete list of provisions of the Kerry-Lieberman bill modeled in this study, along with their assumed economic incidence, see Section VII.
} 
of these provisions is distributed to households based on reported capital income. Because the nation's shareholders are clustered in the top two income quintiles, these provisions dramatically worsen the already regressive gross burden of Kerry-Lieberman.

TABle 8. Annual Benefits Returned to Households by the KerRy-Lieberman BILl BY INCOME QUINTILE (2008 DOLLARS)

\begin{tabular}{|c|c|c|c|c|c|}
\hline & \multicolumn{5}{|c|}{ Quintiles of Household Cash Money Income } \\
\hline & $\begin{array}{c}\text { Bottom } 20 \\
\text { Percent }\end{array}$ & $\begin{array}{c}\text { Second } 20 \\
\text { Percent }\end{array}$ & $\begin{array}{l}\text { Third } 20 \\
\text { Percent }\end{array}$ & $\begin{array}{c}\text { Fourth } 20 \\
\text { Percent }\end{array}$ & $\begin{array}{c}\text { Top } 20 \\
\text { Percent }\end{array}$ \\
\hline Electricity Consumers & $\$ 46$ & $\$ 128$ & $\$ 215$ & $\$ 339$ & $\$ 1,095$ \\
\hline Natural Gas Consumers & $\$ 12$ & $\$ 33$ & $\$ 55$ & $\$ 87$ & $\$ 282$ \\
\hline Home Heating Oil and Propane Consumers & $\$ 8$ & $\$ 13$ & $\$ 14$ & $\$ 20$ & $\$ 23$ \\
\hline Consumer Relief & $\$ 268$ & $\$ 146$ & $\$ 75$ & $\$ 43$ & $\$ 20$ \\
\hline Trade Exposed Industries & $\$ 20$ & $\$ 55$ & $\$ 92$ & $\$ 145$ & $\$ 469$ \\
\hline Refiners & $\$ 5$ & $\$ 14$ & $\$ 23$ & $\$ 36$ & $\$ 117$ \\
\hline Comm'I Deploy. of Carbon Capture and Sequestration & $\$ 6$ & $\$ 16$ & $\$ 28$ & $\$ 44$ & $\$ 141$ \\
\hline Clean Vehicle Technology & $\$ 1$ & $\$ 4$ & $\$ 6$ & $\$ 10$ & $\$ 31$ \\
\hline Highway Trust Fund & $\$ 6$ & $\$ 11$ & $\$ 17$ & $\$ 23$ & $\$ 47$ \\
\hline Grants for National Surface Transportation System & $\$ 6$ & $\$ 11$ & $\$ 17$ & $\$ 23$ & $\$ 47$ \\
\hline Total Annual Benefits & $\$ 379$ & $\$ 431$ & $\$ 542$ & $\$ 769$ & $\$ 2,274$ \\
\hline Benefits as a \% of Household Income & $3.7 \%$ & $1.6 \%$ & $1.1 \%$ & $1.0 \%$ & $1.4 \%$ \\
\hline
\end{tabular}

Source: Chamberlain Economics, L.L.C.; the "American Power Act."

Some provisions in the bill are less regressive or are slightly progressive. These include the "home heating oil and propane consumers" program, ${ }^{24}$ and two programs for highway and other surface transportation grants. ${ }^{25}$ The program for home heating oil and propane consumers directly distributes refunds to consumers of propane and natural gas, and these benefits are distributed to households based on reported expenditures on these fuels. The programs that support the Highway Trust Fund and other surface transportation benefit households and firms indirectly by providing improved road transportation services. Following the expenditure incidence method outlined by Chamberlain and Prante (2007), ${ }^{26}$ these benefits are distributed half to households based on reported oil and gasoline expenditures as a proxy for road usage, and half to households based on capital income as a proxy for the benefit of improved roads to owners of U.S. companies.

Among the bill's allowance distributions, the only one specifically targeted at lowincome households in 2020 is the "program for consumer relief."27 This provision reserves 12.3 percent of allowances, which are auctioned with the proceeds distributed directly to low-income households. We distribute these benefits to households on the basis of reported income from public assistance and food stamps.

\footnotetext{
${ }^{24}$ See "American Power Act," Section 781(a)(3).

${ }^{25}$ See "American Power Act," Section 781(f)(1-3).

${ }^{26}$ See Andrew Chamberlain and Gerald Prante (2007), "Who Pays Taxes and Who Receives Government Spending? An Analysis of Federal, State and Local Tax and Spending Distributions, 1991-2004." Tax Foundation Working Paper No. 1, Section III.

${ }^{27}$ See "American Power Act," Section 781(a)(4). The bill also establishes a "Universal Trust Fund" program that distributes cash rebates to U.S. households, but this program does not begin phasing-in until 2026, six years after the year modeled in this study.
} 
The combined effect of these provisions is that most benefits flow to families in the top income quintile. This is mostly due to the large number of allowances granted freely to industries in the Kerry-Lieberman bill, which in turn benefits shareholders that are clustered in the top two quintiles. The benefits targeted at low-income consumers are relatively small in comparison, only offsetting a small fraction of the bill's regressivity.

Table 9 presents the net burden of the Kerry-Lieberman bill to U.S. households. In the top line we present the gross burden estimates from Table 4. In the second line, we subtract off the value of any benefits received from the bill's allowance distributions. The third line presents the net annual burden — or net benefit— to households in each income group from the bill.

TABle 9. Net Household BuRdens From KerRy-Lieberman by InCOME Group (Positive Amounts Indicate Net Costs; Negative Amounts Indicate Net Benefits)

\begin{tabular}{lccccc}
\hline & \multicolumn{4}{c}{ Quintiles of Household Cash Money Income } \\
\cline { 2 - 6 } & $\begin{array}{c}\text { Bottom 20 } \\
\text { Percent }\end{array}$ & $\begin{array}{c}\text { Second 20 } \\
\text { Percent }\end{array}$ & $\begin{array}{c}\text { Third 20 } \\
\text { Percent }\end{array}$ & $\begin{array}{c}\text { Fourth 20 } \\
\text { Percent }\end{array}$ & $\begin{array}{c}\text { Top 20 } \\
\text { Percent }\end{array}$ \\
\hline Gross Annual Burden from Kerry-Lieberman & $\$ 536$ & $\$ 754$ & $\$ 952$ & $\$ 1,206$ & $\$ 1,764$ \\
Less: Household Benefits Received & $\$ 379$ & $\$ 431$ & $\$ 542$ & $\$ 769$ & $\$ 2,274$ \\
\hline Net Annual Burden from Kerry-Lieberman & $\$ 157$ & $\$ 323$ & $\$ 410$ & $\$ 437$ & $(\$ 510)$ \\
Net Burden as a \% of Income & $1.5 \%$ & $1.2 \%$ & $0.9 \%$ & $0.6 \%$ & $-0.3 \%$ \\
Aggregate Net Burden (\$ billion) & $\$ 3.8$ & $\$ 7.8$ & $\$ 9.9$ & $\$ 10.5$ & $(\$ 12.3)$ \\
\hline \hline
\end{tabular}

Source: Chamberlain Economics, L.L.C.

Under our modeling assumptions, the nation's highest-income households stand to profit considerably from the Kerry-Lieberman bill. Although these households pay the highest gross burden from cap-and-trade, they also receive the most benefits. Once the bill's full effects are accounted for these households profit on average by an estimated $\$ 510$ per year. By contrast, all other income groups bear a positive net burden, ranging from $\$ 157$ for households in the bottom quintile to $\$ 437$ for households in the fourth quintile. In total, the bill's skewed distribution of free allowances toward shareholders would lead to an effective fiscal redistribution of roughly $\$ 12.3$ billion per year from households in the bottom 80 percent of incomes to the highest-earning 20 percent of households.

Figure 14 and 15 present the estimates from Table 9 graphically. Figure 14 shows the net dollar burden of Kerry-Lieberman by income quintile, while Figure 15 presents net burdens as a percentage of income. Each of the bottom four quintiles bear a positive net burden, with the heaviest costs falling on households in the three middle-income quintiles. By contrast, households in the top quintile would not only bear zero net burden, but would also profit on average by roughly $\$ 510$ per year under the bill. 
Figure 14. Net Household Burdens From KeRRY-Lieberman by INCOME GROUP (Positive Amounts Indicate Net Costs; Negative Amounts Indicate Net Benefits)

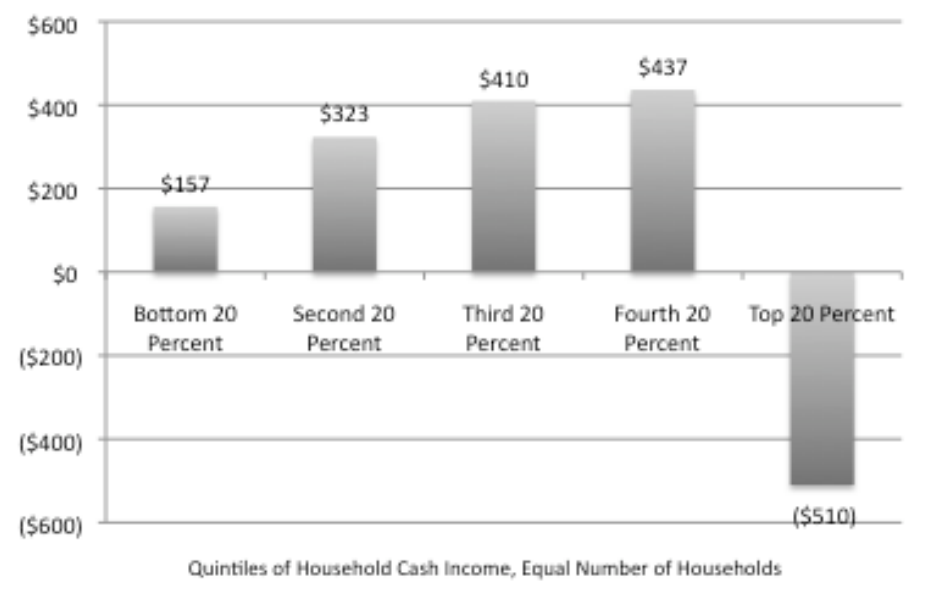

Source: Chamberlain Economics, L.L.C.

Figure 15. Net Burdens From Kerry-Lieberman As a Percentage of Income (Positive Amounts Indicate Net Costs; Negative Amounts Indicate Net Benefits)

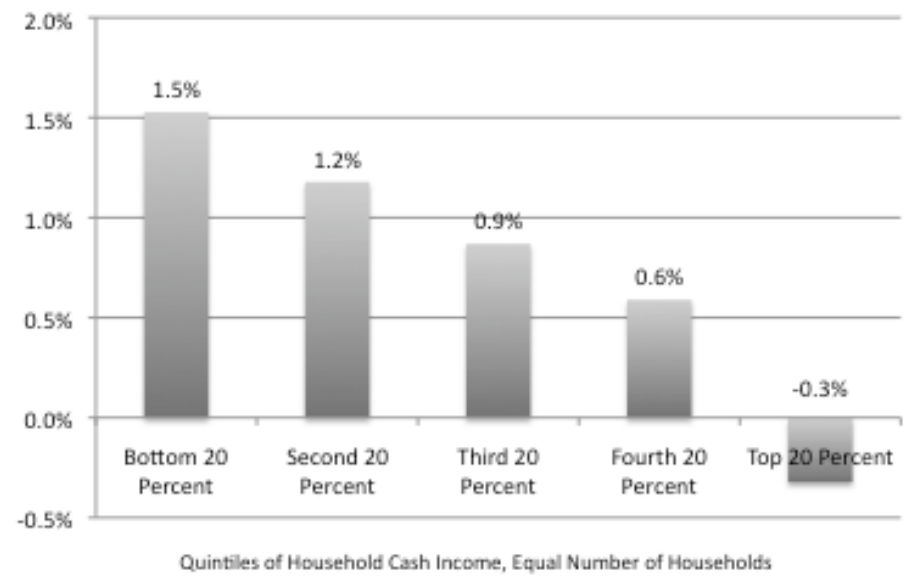

Source: Chamberlain Economics, L.L.C.

Many advocates of climate policy have argued that the regressive impact of cap-and-trade can be eliminated by an appropriate distribution of free allowances to low-income households. If this were done, the Kerry-Lieberman bill could have been made progressive overall despite its regressive gross burdens. But as Figure 14 makes clear, the authors of the bill did not follow this approach. By failing to address one of the most fundamental criticisms of cap-and-trade - the policy's regressive impact on householdsthe Kerry-Lieberman bill illustrates the large and persistent intellectual gap between the academic theory and legislative practice of climate policy in the U.S. 


\section{F. Impact on CONSUMER Prices}

The basic mechanism by which cap-and-trade burdens are shifted from companies to households is higher consumer prices. In general, carbon-intensive products like electricity, petroleum and natural gas - or those that rely on these products as productive inputs - would face the largest price increases under Kerry-Lieberman. Because nearly all industries make some use of fossil fuels, the costs of the bill would tend to be highly diffused throughout prices across the economy.

Table 10 shows estimates of the Kerry-Lieberman bill's impact on commodity-level prices for 20 product categories produced by U.S. industries. As expected, products experiencing the largest price increases from the bill are produced by the petroleum, electric power generation and natural gas distribution industries, all of which are producers or primary users of carbon-intensive products.

Prices for petroleum and coal products would increase by an estimated 14.6 percent; natural gas prices would rise by 14.1 percent; and electric power generation, transmission and distribution would rise by 11.9 percent. In addition, a variety of chemicals, metals, services and household products would also experience significant price increases from the bill.

This diffuse nature of the price increases caused by cap-and-trade not only make it difficult for lawmakers to control who bears the burden of the policy, but also helps disguise the bill's overall cost to households by embedding them into the price of a wide variety of consumer products throughout the economy.

TABle 10. Estimated IMPACT OF THE KeRry-LiEBerman BILL on VARious U.S. CONSUMER PRiCes (2020)

\begin{tabular}{lccc}
\hline Commodity & $\begin{array}{c}\text { Percentage } \\
\text { Price Increase }\end{array}$ & $\begin{array}{c}\text { Distribution of Cap } \\
\text { and Trade Burden }\end{array}$ & $\begin{array}{c}\text { Percentage of } \\
\text { Total Burden }\end{array}$ \\
\hline Petroleum and coal products & $14.6 \%$ & $\$ 24,564,132,326$ & $19.5 \%$ \\
Natural gas distribution & $14.1 \%$ & $5.4 \%$ & $12.4 \%$ \\
Electric power generation, transmission, and distribution & $11.9 \%$ & $\$ 15,59,211,698$ & $1.0 \%$ \\
Coal mining & $11.6 \%$ & $\$ 1,235,273,45,45$ & $1.7 \%$ \\
Primary ferrous metal products & $6.1 \%$ & $\$ 2,118,202,938$ & $2.9 \%$ \\
Basic chemicals & $6.0 \%$ & $\$ 3,596,440,169$ & $1.2 \%$ \\
State and local government enterprises & $5.6 \%$ & $\$ 1,521,276,380$ & $0.5 \%$ \\
Pipeline transportation & $5.6 \%$ & $\$ 651,443,956$ & $0.9 \%$ \\
Water, sewage and other systems & $5.2 \%$ & $\$ 1,170,121,634$ & $1.1 \%$ \\
Resins, rubber, and artificial fibers & $4.0 \%$ & $\$ 1,332,000,877$ & $0.3 \%$ \\
Agricultural chemicals & $3.1 \%$ & $\$ 356,992,836$ & $0.1 \%$ \\
Metal ores mining & $2.8 \%$ & $\$ 116,991,914$ & $1.2 \%$ \\
Air transportation & $2.7 \%$ & $\$ 1,459,187,741$ & $0.3 \%$ \\
Paints, coatings, and adhesives & $2.5 \%$ & $\$ 364,981,999$ & $0.4 \%$ \\
Other chemical products & $2.4 \%$ & $\$ 460,239,257$ & $0.4 \%$ \\
Transit and ground passenger transportation & $2.3 \%$ & $\$ 487,796,130$ & $0.2 \%$ \\
Nonmetallic mineral mining and quarrying & $2.3 \%$ & $\$ 228,598,481$ & $0.7 \%$ \\
Pulp, paper, and paperboard & $2.3 \%$ & $\$ 934,731,706$ & $0.5 \%$ \\
Courier and messenger services & $2.0 \%$ & $\$ 648,172,287$ & $0.4 \%$ \\
Primary nonferrous metal products & $2.0 \%$ & $\$ 508,019,719$ & $49.0 \%$ \\
All others (114 industries) & $<2.0 \%$ & $\$ 61,696,459,569$ & $100.0 \%$ \\
\hline Total & n.a. & $\$ 125,895,231,885$ & \\
\hline \hline
\end{tabular}

Note: Complete table of 134 commodity-level price impacts is available from the authors upon request. Distribution of cap-and-trade burden is determined by weighting price impacts by total commodity output. Source: Chamberlain Economics, L.L.C. Input-Output Model. 


\section{BENEFITS DISTRIBUTED TO U.S. INDUSTRIES}

A key feature of any cap-and-trade system is how lawmakers choose to distribute emission allowances. While allowance distributions do not affect overall climate goalsemissions are capped regardless of who receives allowances - they have an enormous impact on the distributional fairness and broader economic costs of the policy.

As with the Waxman-Markey bill, the Kerry-Lieberman bill would distribute the vast majority of emission allowances freely to companies and others in the early years of the program. In this section we review the economic theory of how emission allowances should ideally be distributed, and compare this to how allowances were actually divided among companies, government agencies and others in the Kerry-Lieberman bill.

\section{A. How Should Allowances Be Distributed?}

Given that Congress wishes to enact a cap-and-trade system - rather than, say, a broadbased emissions tax - most economists agree the first-best policy is one that fully auctions all emission allowances. Under full auctioning, auction proceeds can be used to cut distortionary taxes - such as personal income, payroll or corporate income taxesand compensate low-income families to alleviate the regressive impact of cap-and-trade. Full auctioning also helps discourage economically wasteful "rent-seeking" behavior by firms who would otherwise lobby for subsidies in the form of free allowances. For these reasons, most experts view full auctioning as the first-best approach to cap-and-trade. ${ }^{28}$

In practice, few Members of Congress have shown interest in full auctioning of allowances. Both the Waxman-Markey and the Kerry-Lieberman bills distribute large numbers of allowances freely to industries and others. Given that the first-best policy of full auctioning is unlikely to occur, a second-best option favored by many economists is to distribute free allowances using an emissions-based rule that compensates firms for the harmful short-run effects of cap-and-trade on profits and share prices in their industry. ${ }^{29}$

Under this approach, lawmakers would distribute free allowances to industries based on the share of greenhouse gas emissions they would be responsible for under the bill. For example, if an industry were responsible for one-fourth of covered emissions, the bill would distribute 25 percent of authorized allowances freely to firms in that industry. Under this approach, industries with large emissions most heavily affected by cap-andtrade would also receive the most generous compensation. This system has the advantage of fully compensating shareholders for losses due to climate policy, but would still

\footnotetext{
${ }^{28}$ For a detailed survey of expert opinion on free vs. full auctioning of cap-and-trade allowances, see Alan D. Viard, "Don't Give Away the Cap-and-Trade Permits!” Tax Notes. (May 4, 2009).

${ }^{29}$ For a discussion of this approach and estimates of the number of allowances required to fully compensate various industries, see Lawrence Goulder, "Mitigating the Adverse Impacts of CO2 Abatement Policies on Energy-Intensive Industries,” Resources for the Future Discussion Paper 02-22 (2002).
} 
discourage wasteful industry "rent seeking" by relying on a transparent and reasonably objective criterion for distributing free allowances.

Unfortunately, the Kerry-Lieberman bill follows neither the first-best or second-best approach. In terms of the first-best approach of full auctioning, the bill clearly fails, distributing an average of 77 percent of allowances freely between 2013 and 2030, while auctioning less than one-fourth. The bill deviates so dramatically from the first-best policy of full auctioning that this approach was clearly never considered as a viable option among lawmakers facing intense lobbying pressure from U.S. industries.

In terms of the second-best approach, the Kerry-Lieberman bill also fails. Figure 16 shows the distribution of free allowances under Kerry-Lieberman among the three covered industries most affected by the bill: electricity, natural gas local distribution, and petroleum refining. These three industries are responsible for the overwhelming majority of emissions under the bill. In the figure, the dark-gray bar represents emissions each industry would be responsible for, while the light-gray bar represents free allowances they would receive in 2020 , seven years into the program.

Figure 16. Free EMission Allowances Granted by KerRy-Lieberman COMPARED TO COVERED INDUSTRY EMISSIONS (2020)

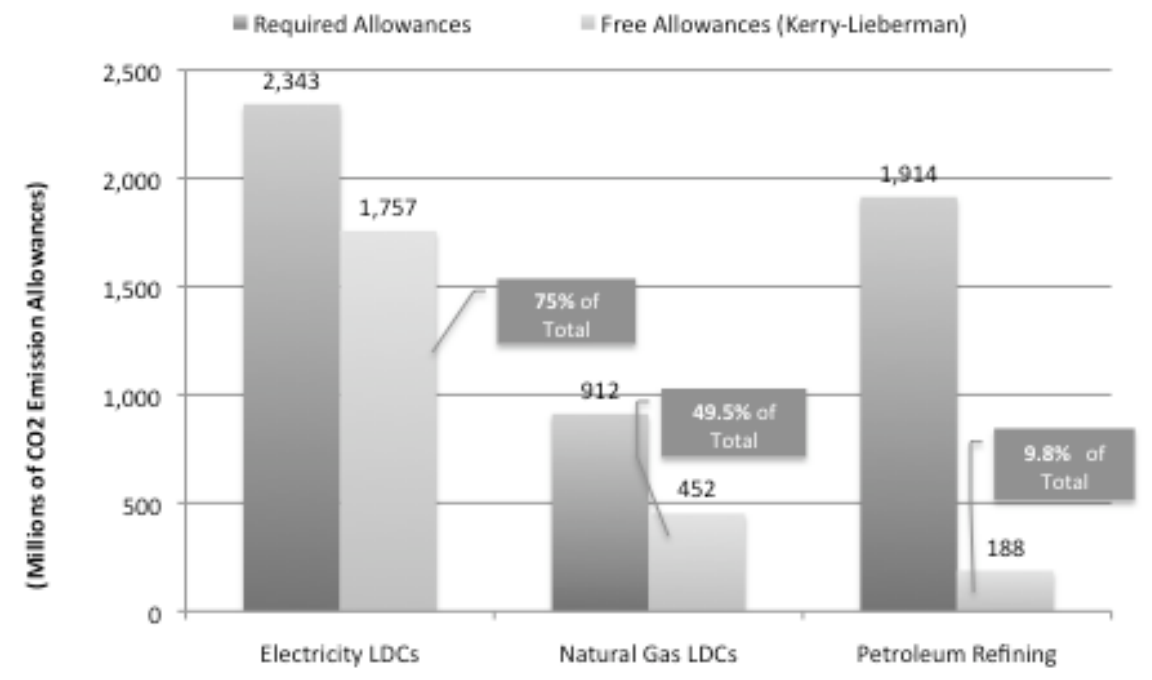

Source: Chamberlain Economics, L.L.C.

Clearly, the pattern of free allowances in the bill fails to satisfy even the second-best approach of compensating industries for harm suffered from cap-and-trade. The bill dramatically overcompensates some industries compared to emissions shares while severely under-compensating others. Electricity companies receive the most generous compensation, equal to 75 percent of covered emissions. Natural gas local distribution companies - who are responsible for the smallest share of emissions under the billreceive a similarly generous share of free allowances, equal to 49.5 percent of covered emissions. By contrast, petroleum refineries that are responsible for the second-largest share of emissions under the bill receive little compensation, just 9.8 percent of covered emissions. 
By failing to follow both the first-best and second-best approaches to distributing allowances, the Kerry-Lieberman bill suggests another possible factor driving the bill's structure: aggressive "rent seeking" behavior by U.S. industries. To the extent that firms are granted free allowances in excess of their emission shares, firms in those industriesand ultimately the shareholders of those firms-will enjoy a politically generated windfall profit in the form of valuable emission allowances.

In the following section, we highlight the economic "winners" and "losers" from the political bargaining process that occurred among U.S. industries and lawmakers during the period preceding the unveiling of the Kerry-Lieberman bill.

\section{B. Allowance Distributions in KerRy-Lieberman}

The Kerry-Lieberman bill distributes a large number of emission allowances freely to various industries, government agencies and others during the first two decades of the system. Beginning in 2013, the bill auctions just 24.8 percent of allowances with the remaining 75.2 percent distributed freely to local distributors of electricity and natural gas, "trade exposed" industries, alternative fuel vehicle producers, companies engaged in carbon capture and sequestration and others. By 2020, the share of free allowances rises to 79.25 percent, with less than one-fifth auctioned. On average, the bill distributes 77 percent of allowances freely between 2013 and 2030 .

Figure 17 illustrates the distribution of emissions allowances under Kerry-Lieberman over the life of the bill between 2013 and 2050. Because the bill's allowance allocations are unchanged from 2035 onward, the figure excludes the last decade of data.

Figure 17. Free vs. Auctioned Allowances in Kerry-Lieberman, 2013-2050

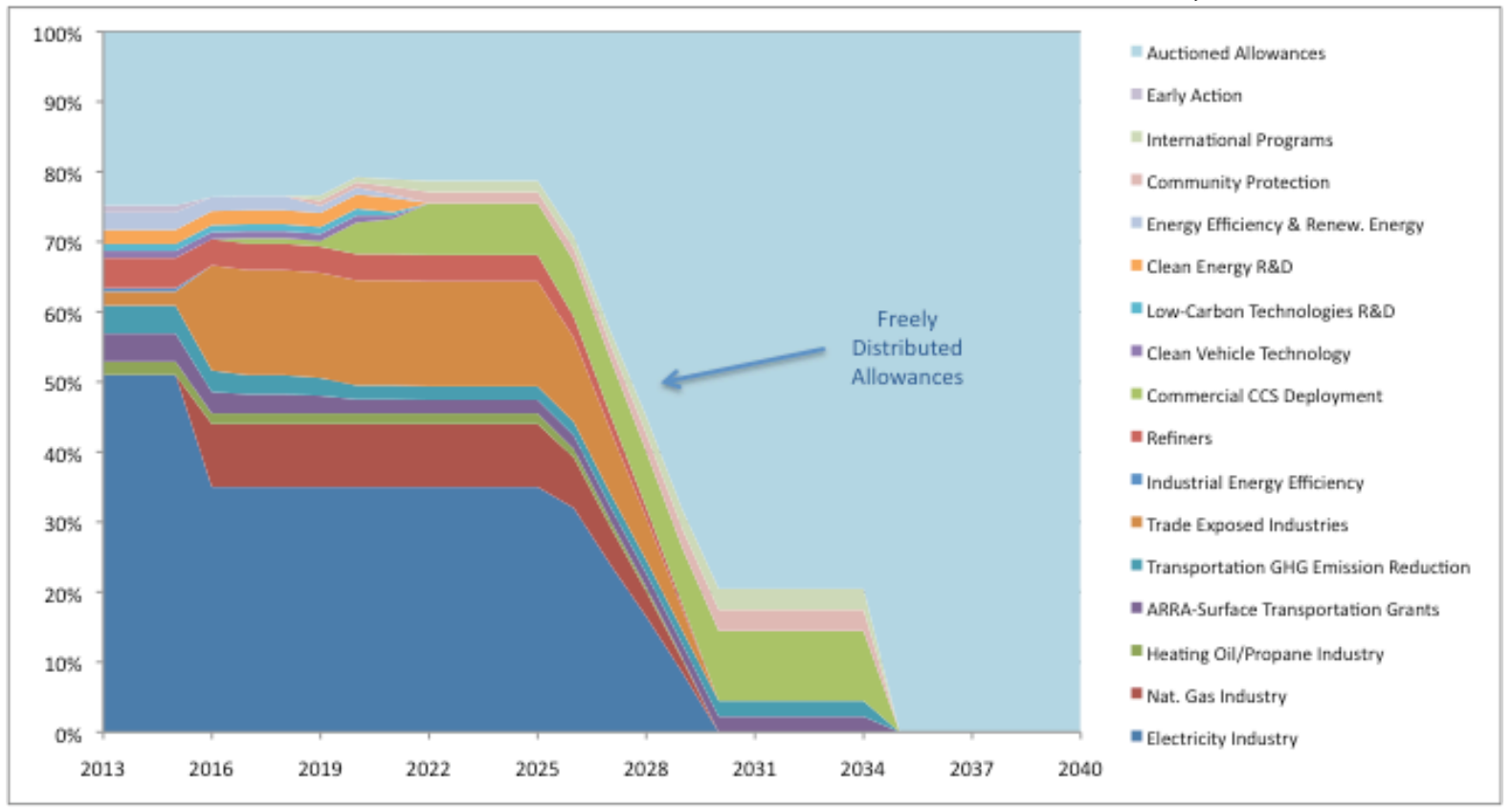

Source: Chamberlain Economics, L.L.C.; the "American Power Act" 
Beginning in 2026, the bill slowly reduces the share of free allowances and increases the share sold via auction. By 2030 the split between free and auctioned allowances is largely reversed, with fully 100 percent of allowances auctioned by 2035 . The allowance distributions remain unchanged from 2035 onward.

\section{Opportunity Cost of Free Allowances}

From a lawmaker's perspective, the main disadvantage of freely distributing allowances is the lost opportunity to generate auction revenue that can be used to improve the fairness and efficiency of cap-and-trade. With full auctioning, auction proceeds can be used to cut economically harmful income and payroll taxes, or otherwise offset costs to households. This opportunity is lost when allowances are distributed freely. In this way, free allowances represent a real economic cost to the U.S. Treasury-in economic jargon, an "opportunity cost"- equal to the loss of federal revenue that could have been put to beneficial use.

Table 11 shows the value of free allowances distributed under the Kerry-Lieberman bill between 2013 and 2034. The calculations are based on the quantity of allowances specified by the bill, along with a forecast of allowance prices in various years. ${ }^{30}$

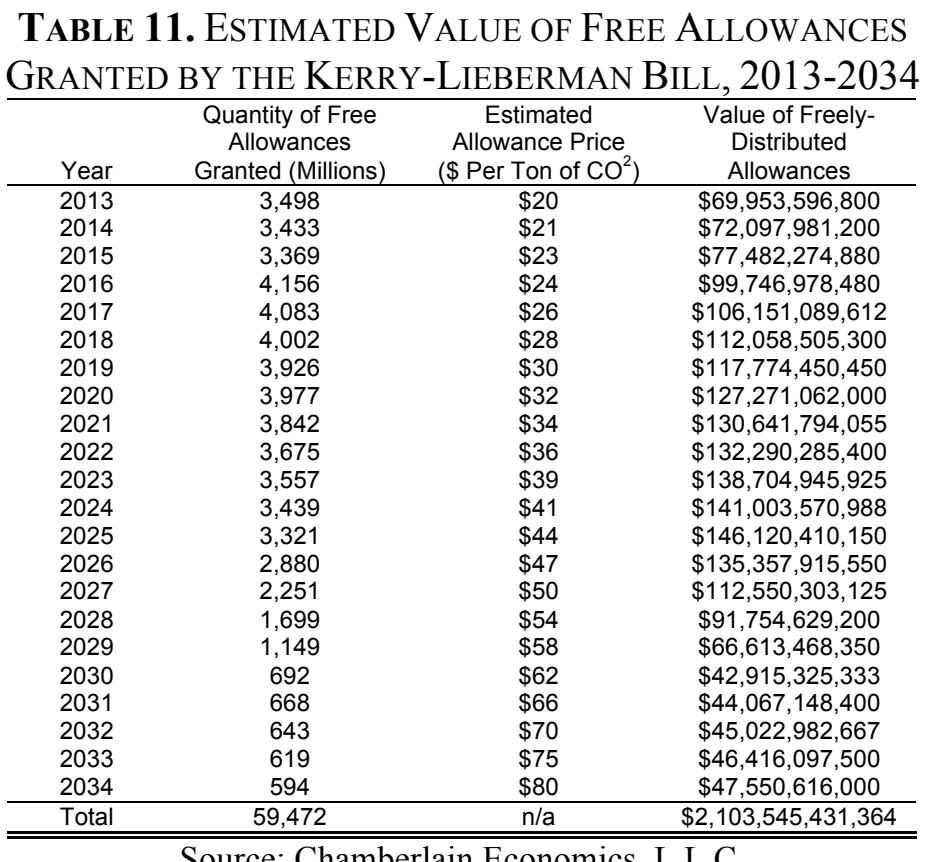

Source: Chamberlain Economics, L.L.C.

Between 2013 and 2034, the proposal gives away an average of $\$ 95.6$ billion per year worth of allowances to various industries, government agencies and others. In total, the bill's free allowances represent a gross loss of roughly $\$ 2.1$ trillion in federal revenue

\footnotetext{
${ }^{30}$ The allowance price forecast is based on a mid-point of the upper and lower price boundaries established by the bill's allowance "price collar," as specified in Section 726(b) and Section 790(d).
} 
over the life of the bill, a staggering figure roughly equal to total U.S. federal revenue from all sources in 2009. ${ }^{31}$

To illustrate the magnitude of this foregone revenue-and thus the opportunity cost of free allowances compared with an emissions tax or full auctioning - this $\$ 2.1$ trillion cost is also:

- Equal to roughly 90 percent of the U.S. economy's total health care expenditures in 2008 (\$2.34 trillion). ${ }^{32}$

- Equal to roughly 99.5 percent of mandatory federal spending in 2009 (\$2.11 trillion), including large programs such as Medicare, Medicaid, Social Security and the Troubled Assets Relief Program (TARP). ${ }^{33}$

- Equal to more than 16 percent in total outstanding federal government debt (\$13.06 trillion). ${ }^{34}$

${ }^{31}$ See U.S. Office of Management and Budget, "Budget Summary Tables for Fiscal Year 2011,"available at www.whitehouse.gov/omb/.

${ }^{32}$ See U.S. Department of Health and Human Services, "National Health Expenditures Web Tables 19602008".

${ }^{33}$ See U.S. Office of Management and Budget, supra note 31.

${ }^{34}$ See U.S. Bureau of the Public Debt, "Total Public Debt Outstanding," available at www.publicdebt.treas.gov. 


\section{BENEFITS TO SPECIFIC INDUSTRIES}

The Kerry-Lieberman bill does not distribute free allowances to all industries equally. Instead, it singles out a select few for a particularly large share of free allowances. In this section we examine free allowances granted to four industries: electric utilities, "tradeexposed" industries, companies engaged in "carbon capture and sequestration," and natural gas local distribution companies. Between 2013 and 2029, these four sectors receive 77 percent of all free allowances, for a total subsidy of roughly $\$ 1.6$ trillion over the life of the bill.

\section{i. Electricity Industry}

The single largest groups of recipients of free allowances are electricity local distribution companies (LDCs). In 2013, electric utilities and merchant coal generators receive 51 percent of total allowances-more than four times larger than the allocation for the "consumer relief program," the second largest program in that year. The industry's share of free allowances falls to 35 percent in 2016. In 2025 the bill slowly begins phasing out free allowances to electricity LDCs, reaching zero in 2030.

Table 12 and Figure 18 present estimates of the value of free allowances distributed to the electricity industry between 2013 through 2029.

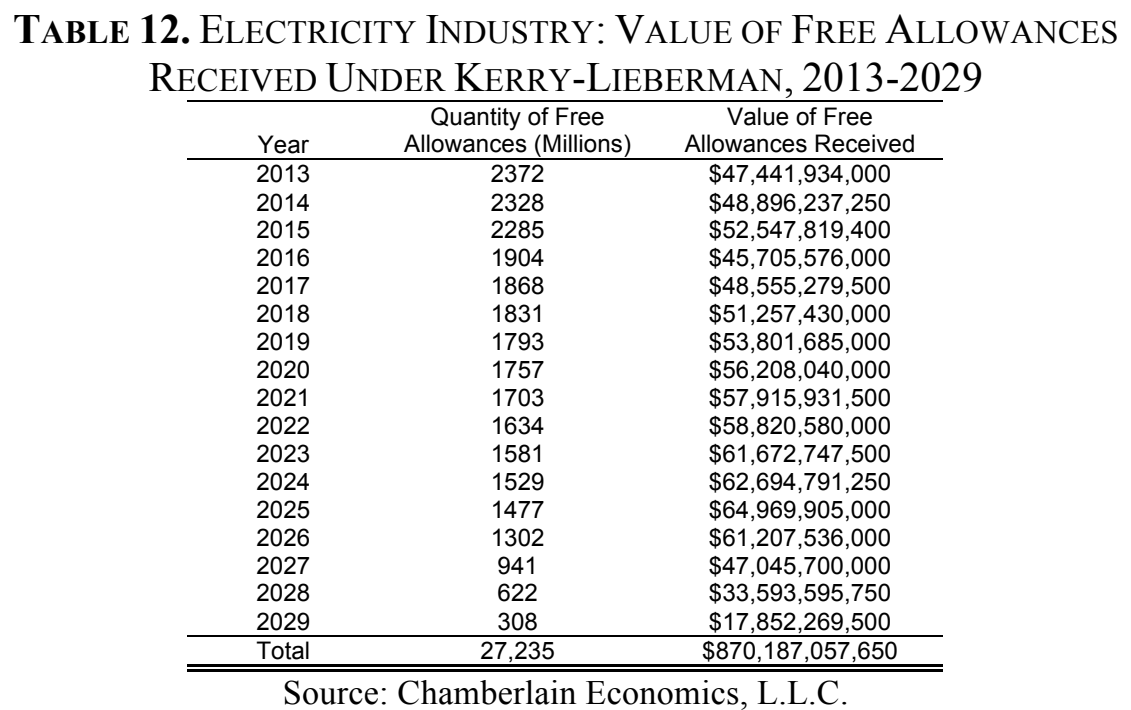

Under the Kerry-Lieberman bill, electricity firms would enjoy between $\$ 17.9$ billion and $\$ 65$ billion per year in free allowances, for a grand total of $\$ 870$ billion over the life of the bill-more than one and a half times greater than the U.S. Department of Defense's discretionary funding for $2009 .{ }^{35}$ This would represent a tremendous transfer of wealth to a single U.S. industry, equivalent to spending the entire 2009 stimulus package intended to revive the U.S. economy on a single industry ( $\$ 787$ billion).

\footnotetext{
${ }^{35}$ See U.S. Office of Management and Budget, supra note 31.
} 
Figure 18. EleCtricity Industry: Value of Free Allowances

RECEIVED UNDER KERRY-LIEBERMAN, 2013-2029

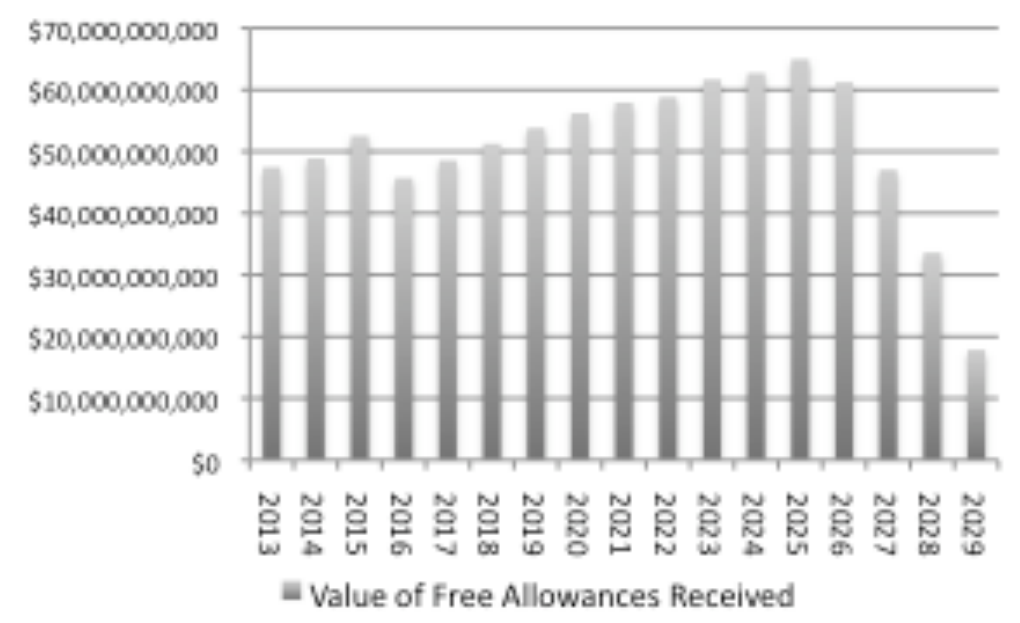

Source: Chamberlain Economics, L.L.C.

While the text of the Kerry-Lieberman bill specifies that electricity LDCs must use free allowances "for the benefit of" consumers, as explained in Section II there are strong theoretical reasons to doubt ratepayers will be the primary beneficiaries of the subsidies granted to electricity LDCs by the bill. Instead, the profit-maximizing behavior of utilities under state and local regulation is likely to channel at least some portion of these financial benefits to utility shareholders rather than consumers.

\section{ii. “Trade-Exposed" Industries}

The second-largest recipient of free allowances is a collection of industries designated as "trade-exposed" by lawmakers. These industries, including textiles, steel, and agriculture, generally face intense international competition in the marketplace. Because they are perceived as being less able to pass through the costs of cap-and-trade to consumers - in the language of economics, they face relatively "elastic" demand for their products - the bill confers benefits to them.

The Kerry-Lieberman bill begins distributing free allowances to trade exposed industries immediately in 2013, three years before they become covered entities under the bill. The allocation of permits to trade exposed industries begins at 2 percent of total allowances, increasing to 15 percent in 2016 where it remains through 2025 , slowly falling to zero in 2030.

Table 13 and Figure 19 present estimates of the value of free allowances distributed to trade exposed industries by the Kerry-Lieberman bill. Between 2013 and 2029, the bill would transfer between $\$ 1.86$ billion and $\$ 27.8$ billion per year to these companies, for a grand total of $\$ 305.6$ billion over the life of the bill. That amounts to an industry subsidy 
that is $\$ 9$ billion larger than all U.S. imports from China in $2009,{ }^{36}$ and roughly equal to twice the size of the 2008 AIG "bailout."37

TABle 13. “Trade Exposed” Industries: Value of Free Allowances RECEIVED UNDER KERRY-LIEBERMAN, 2013-2029

\begin{tabular}{ccc}
\hline Year & $\begin{array}{c}\text { Quantity of Free } \\
\text { Allowances (Millions) }\end{array}$ & $\begin{array}{c}\text { Value of Free } \\
\text { Allowances Received }\end{array}$ \\
\hline 2013 & 93 & $\$ 1,860,468,000$ \\
2014 & 91 & $\$ 1,917,499,500$ \\
2015 & 90 & $\$ 2,060,698,800$ \\
2016 & 816 & $\$ 19,588,104,000$ \\
2017 & 800 & $\$ 20,809,405,500$ \\
2018 & 785 & $\$ 21,967,470,000$ \\
2019 & 769 & $\$ 23,057,865,000$ \\
2020 & 753 & $\$ 24,089,160,000$ \\
2021 & 730 & $\$ 24,821,113,500$ \\
2022 & 700 & $\$ 25,208,820,000$ \\
2023 & 678 & $\$ 26,431,177,500$ \\
2024 & 655 & $\$ 26,869,196,250$ \\
2025 & 633 & $\$ 27,844,245,000$ \\
2026 & 488 & $\$ 22,952,826,000$ \\
2027 & 353 & $\$ 17,642,137,500$ \\
2028 & 226 & $\$ 12,215,853,000$ \\
2029 & 109 & $\$ 6,300,801,000$ \\
\hline Total & 8,769 & $\$ 305,636,840,550$ \\
\hline \hline
\end{tabular}

Source: Chamberlain Economics, L.L.C.

Figure 19. "Trade Exposed” Industries: Value of Free Allowances RECEIVED UNDER KERRY-LIEBERMAN, 2013-2029

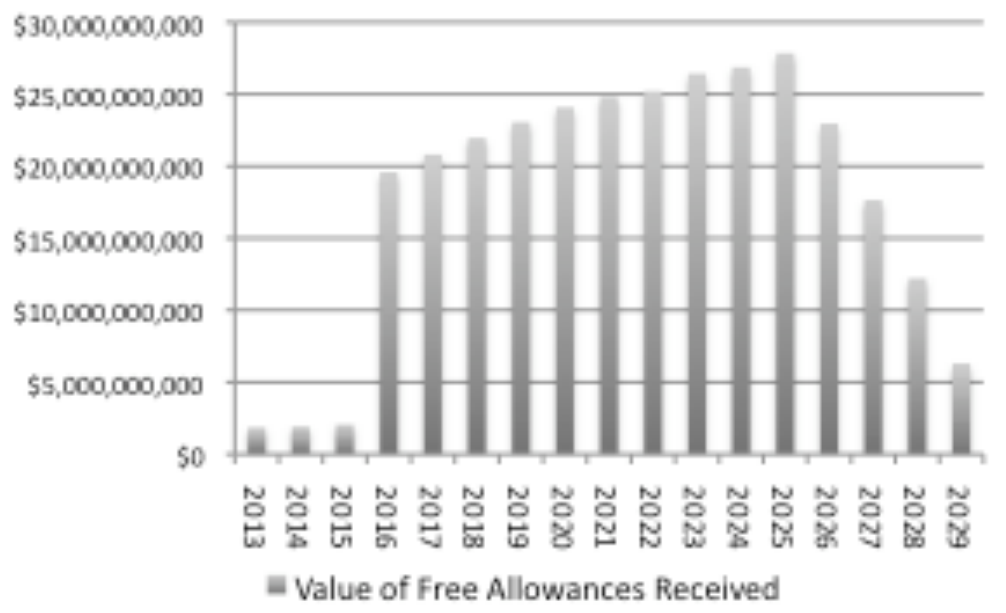

Source: Chamberlain Economics, L.L.C.

\footnotetext{
${ }^{36}$ See U.S. Census Bureau, "U.S. Trade Balance with China: 2009," Foreign Trade Statistics, available at www.census.gov/foreign-trade/balance/c5700.html.

${ }^{37}$ See Carol D. Leonnig, "Effectiveness of AIG's \$143 Billion Rescue Questioned," Washington Post (November 2, 2008).
} 


\section{iii. Carbon Capture and Sequestration Industry}

The third-largest beneficiary of free allowances is the carbon capture and sequestration (CCS) industry. This provision is unusual in that, unlike the electricity and natural gas industries, CCS is a largely new and unproven technology. The National Energy Technology Laboratory is not scheduled to field test CCS technology until 2018-five years after the Kerry-Lieberman bill would go into effect ${ }^{38}$-and the Department of Energy's FutureGen project that was established in 2003 still has yet to break ground on what would be the nation's first CCS power plant.

Free allowances granted to the CCS industry are aimed at subsidizing the installation of carbon capture systems in electricity and industrial plants. However, the industry faces tremendous technical and logistical barriers before the technology will be ready for widespread commercial deployment. For example, supporting infrastructure such as pipelines to carry captured carbon and secure facilities for long-term carbon storage are currently non-existent. Although lawmakers have shown considerable enthusiasm for CCS, the Kerry-Lieberman bill's large subsidy for the industry remains a risky wager on a new and unproven technology.

Beginning in 2017, firms in the CCS industry receive 0.8 percent of total allowances freely. This allocation grows rapidly to 8 percent of allowances by 2026. Even after 2029 when free allowances to other industries end, the CCS industry's free allowances continue growing. The industry receives a substantial 10 percent of total allowances freely from 2030 to 2034, after which free allowances to CCS are phased out.

Table 14. Carbon Capture and Sequestration Industry: Value of Free ALlowANCES ReCEIVED UNDER KERRY-LIEBERMAN, 2013-2034

\begin{tabular}{ccc}
\hline Year & $\begin{array}{c}\text { Quantity of Free } \\
\text { Allowances (millions) }\end{array}$ & $\begin{array}{c}\text { Value of Free } \\
\text { Allowances Received }\end{array}$ \\
\hline 2013 & 0 & $\$ 0$ \\
2014 & 0 & $\$ 0$ \\
2015 & 0 & $\$ 0$ \\
2016 & 0 & $\$ 0$ \\
2017 & 43 & $\$ 1,109,834,960$ \\
2018 & 42 & $\$ 1,171,598,400$ \\
2019 & 41 & $\$ 1,229,752,800$ \\
2020 & 226 & $\$ 7,226,748,000$ \\
2021 & 243 & $\$ 1,273,704,500$ \\
2022 & 345 & $\$ 13,039,351,200$ \\
2023 & 334 & $\$ 13,255,470,900$ \\
2024 & 323 & $\$ 13,736,494,200$ \\
2025 & 312 & $\$ 15,301,884,000$ \\
2026 & 326 & $\$ 15,681,900,000$ \\
2027 & 314 & $\$ 16,287,804,000$ \\
2028 & 302 & $\$ 16,802,136,000$ \\
2029 & 290 & $\$ 20,968,400,000$ \\
2030 & 338 & $\$ 21,531,180,000$ \\
2031 & 326 & $\$ 21,998,200,000$ \\
2032 & 314 & $\$ 22,678,875,000$ \\
2033 & 302 & $\$ 23,233,200,000$ \\
2034 & 290 & $\$ 245,962,914,110$ \\
\hline Total & 4,712 & \\
\hline \hline
\end{tabular}

Source: Chamberlain Economics, L.L.C.

\footnotetext{
${ }^{38}$ See National Energy Technology Laboratory, "Carbon Sequestration FAQ Information Portal," available at www.netl.doe.gov/technologies/carbon_seq/FAQs/tech-status.html.
} 
Table 14 and Figure 20 present estimates of the value of free allowances distributed to the CCS industry by Kerry-Lieberman. The bill distributes between $\$ 1.1$ billion and $\$ 23.2$ billion per year to the industry, for a grand total of $\$ 246$ billion over the life of the bill. By comparison, this amount is roughly twice the size of total government expenditures for the State of California in 2009 (\$124.7 billion), ${ }^{39}$ an amount sufficient to finance all state government activities in the world's $8^{\text {th }}$ largest economy for one year. ${ }^{40}$

Figure 20. Carbon Capture and Sequestration Industry: Value of Free Allowances ReCEIVED Under KeRry-Lieberman, 2013-2034

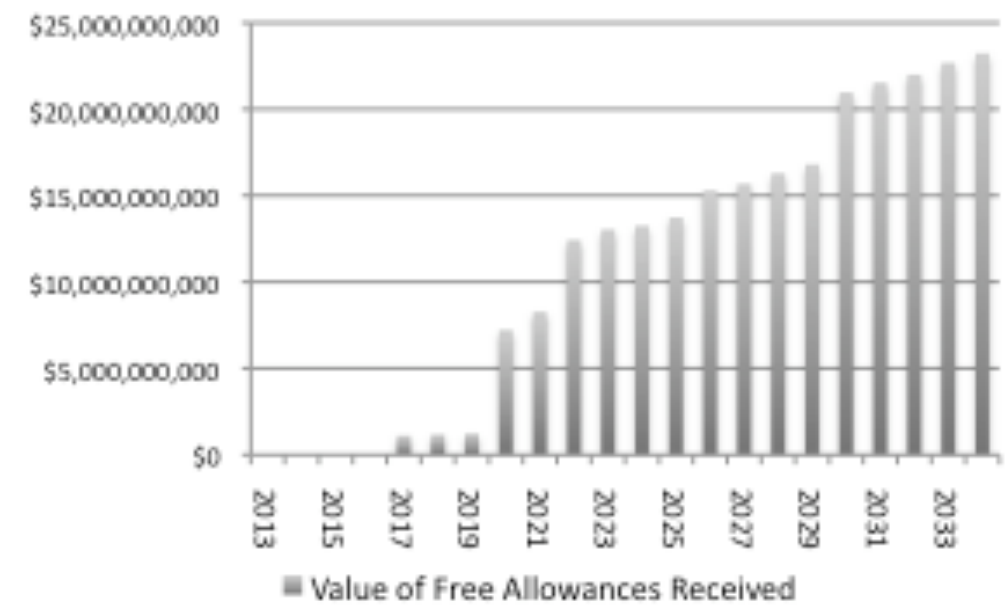

Source: Chamberlain Economics, L.L.C.

\section{iv. Natural Gas Local Distribution Industry}

Another industry singled out for free allowances under the Kerry-Lieberman bill is the natural gas local distribution industry. Natural gas local distribution companies (LDCs) are granted nine percent of total allowances beginning in 2016-the year they would become covered entities under the bill. Their allocation of allowances remains at this level through 2025, declining thereafter until disappearing in 2030.

Table 15 and Figure 21 present the value of allowances received freely by local natural gas distributors. The bill would distribute between $\$ 3.8$ billion and $\$ 16.7$ billion per year to these companies, for a grand total of $\$ 179.9$ billion over the life of the bill. While this amount is substantially less than the subsidy received by the previous three industries, it is still enough to pay for the entire 2009 "Home Affordable Modification Program"- the Obama administration's $\$ 75$ billion failed attempt to rescue overly indebted U.S.

\footnotetext{
${ }^{39}$ See California Department of Finance, "General Funds, Bond Funds and Special Funds Total," Chart B: Historical Data-Budget Expenditures, available at dof.ca.gov/budgeting/budget_faqs/documents/CHARTB.pdf.

${ }^{40}$ See Center for Continuing Study of the California Economy, "2008 California Economy Rankings," Numbers in the News August 2009.
} 
homeowners $^{41}$ - while also financing the euro zone's recent $\$ 105$ billion bailout loan to Greece. $^{42}$

TABLE 15. Natural Gas Local Distribution Industry: Value of FreE ALLOWANCES

\begin{tabular}{ccc} 
RECEIVED UNDER KERRY-LIEBERMAN, 2013-20 \\
\cline { 2 - 3 } Year & $\begin{array}{c}\text { Quantity of Free } \\
\text { Allowances (Millions) }\end{array}$ & $\begin{array}{c}\text { Value of Free } \\
\text { Allowances Received }\end{array}$ \\
\hline 2013 & 0 & $\$ 0$ \\
2014 & 0 & $\$ 0$ \\
2015 & 0 & $\$ 0$ \\
2016 & 490 & $\$ 11,752,862,400$ \\
2017 & 480 & $\$ 12,485,643,300$ \\
2018 & 471 & $\$ 13,180,482,000$ \\
2019 & 461 & $\$ 13,834,719,000$ \\
2020 & 452 & $\$ 14,453,496,000$ \\
2021 & 438 & $\$ 14,892,668,100$ \\
2022 & 420 & $\$ 15,125,292,000$ \\
2023 & 407 & $\$ 15,858,706,500$ \\
2024 & 393 & $\$ 16,121,517,750$ \\
2025 & 380 & $\$ 16,706,547,000$ \\
2026 & 293 & $\$ 13,771,695,600$ \\
2027 & 212 & $\$ 10,585,282,500$ \\
2028 & 136 & $\$ 7,329,511,800$ \\
2029 & 65 & $\$ 3,780,480,600$ \\
\hline Total & 5,097 & $\$ 179,878,904,550$ \\
\hline \hline
\end{tabular}

Source: Chamberlain Economics, L.L.C.

Figure 21. Natural Gas Local Distribution Industry: Value of FreE ALlOWANCES RECEIVED UNDER KERRY-LIEBERMAN, 2013-2029

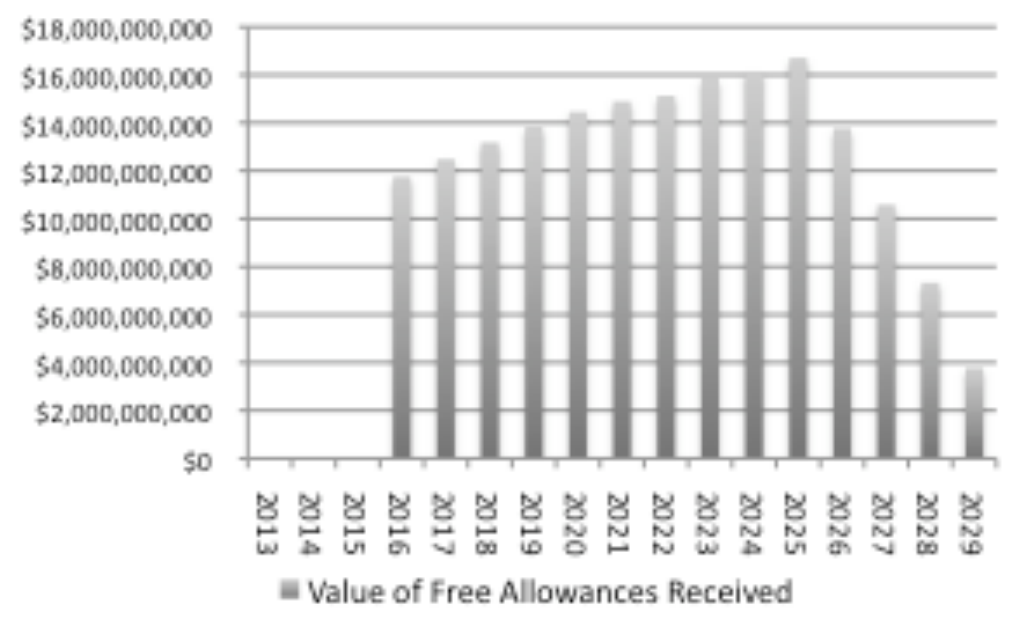

Source: Chamberlain Economics, L.L.C.

\footnotetext{
${ }^{41}$ See Corbett B. Daly, "Lawmakers Slam Top Mortgage Firms on Loan Mods," Reuters (June 24, 2010).

${ }^{42}$ See International Monetary Fund, "IMF Reaches Staff-level Agreement with Greece on $€ 30$ Billion Stand-By Arrangement," Press Release No. 10/176 (May 2, 2010).
} 


\section{IMPACT ON EMPLOYMENT AND HOUSEHOLD EARNINGS}

Because cap-and-trade affects consumer prices for carbon-intensive products, it affects the size and composition of the nation's gross domestic product. In this section, we explore the estimated impact of the Kerry-Lieberman bill on overall U.S. GDP, employment and household earnings during the life of the bill.

\section{A. Reduced U.S. Gross Domestic Product}

Two federal agencies routinely estimate the economic impact of proposed climate policies: the Environmental Protection Agency (EPA) and the Congressional Budget Office (CBO). As of June 2010, only the EPA had released an estimate of the likely impact of Kerry-Lieberman on U.S. GDP. ${ }^{43}$ Table 16 presents EPA's estimates of the bill's impact on gross domestic product between 2015 and 2050. The estimates are based on the agency's IGEM econometric model of the U.S. economy.

TABLE 16. EPA Estimates of Reduced GDP FrOM THE KeRRY-Lieberman BILL

\begin{tabular}{cccc}
\hline Year & $\begin{array}{c}\text { Percentage } \\
\text { Decline in GDP } \\
\text { (EPA Estimate) }\end{array}$ & $\begin{array}{c}\text { Equivalent Dollar Impact on } \\
2008 \text { GDP }\end{array}$ & $\begin{array}{c}\text { Average GDP Decline } \\
\text { Per Household }(2008)\end{array}$ \\
\hline 2015 & $-0.27 \%$ & $-\$ 38,991,780,000$ & $-\$ 323$ \\
2020 & $-0.37 \%$ & $-\$ 53,433,180,000$ & $-\$ 442$ \\
2030 & $-1.45 \%$ & $-\$ 209,400,300,000$ & $-\$ 1,734$ \\
2040 & $-2.03 \%$ & $-\$ 293,160,420,000$ & $-\$ 2,427$ \\
2050 & $-2.66 \%$ & $-\$ 384,141,240,000$ & $-\$ 3,181$ \\
\hline \hline
\end{tabular}

Source: U.S. Environmental Protection Agency; Chamberlain Economics, L.L.C.

According to EPA estimates, the Kerry-Lieberman cap-and-trade bill would reduce the nation's GDP by 0.27 percent in 2015 compared to a baseline of no climate policy. The bill's negative impact grows over time, rising to 2.66 percent of GDP by 2050 . To visualize this impact in today's dollars, columns three and four of the table present 2008equivalent estimates of the bill's impact both in total dollars and dollars per household. That is, columns three and four show what the impact would be on today's economy if lawmakers enacted a policy today that was equivalent to the Kerry-Lieberman bill, as specified in each future year listed in the table.

As is clear from the table, the bill's impact on GDP grows rapidly over time as the greenhouse gas emissions cap becomes more stringent. The bill is estimated to reduce GDP by the equivalent of roughly $\$ 39$ billion in 2015 , rising to more than $\$ 384$ billion by 2050. On a per household basis, the bill is estimated to reduce GDP by the equivalent of roughly $\$ 323$ per household in 2015 . By 2050 , by bill will reduce per-household GDP by more than $\$ 3,181{ }^{44}$

\footnotetext{
${ }^{43}$ See U.S. Environmental Protection Agency, "EPA Analysis of the American Power Act in the 111th Congress, Appendix." (June 14, 2010).

${ }^{44}$ Note that GDP measures only the value of final goods and services produced, and is therefore not a comprehensive measure of economic well-being. Leisure, household production, environmental quality and other factors that affect welfare are not captured by GDP. These limitations should be kept in mind when interpreting the estimates in this section.
} 


\section{A. EFFECT ON EMPLOYMENT AND HouseHold EARNINGS}

Using input-output analysis, it is possible to estimate how these reductions in GDP caused by the Kerry-Lieberman bill would in turn affect employment and household earnings. Input-output analysis uses an accounting framework in which each U.S. industry buys inputs from itself and other industries, and sells the resulting output as intermediate goods to other industries or as final demand to consumers, governments and the rest of the world. These economic linkages are typically presented in an input-output or "Leontief" table.

The "Regional Impact Modeling System" (RIMS II) from the U.S. Bureau of Economic Analysis provides regional multipliers that can be used to estimate order-of-magnitude effects of a policy-induced change in GDP — such as from the Kerry-Lieberman cap-andtrade bill - on the level of employment and total household earnings. ${ }^{45}$ In effect, each dollar of GDP requires a certain number of jobs and household earnings to produce it. When a policy reduces GDP, we can therefore use RIMS II multipliers to approximate the number of lost jobs and the corresponding drop in household earnings.

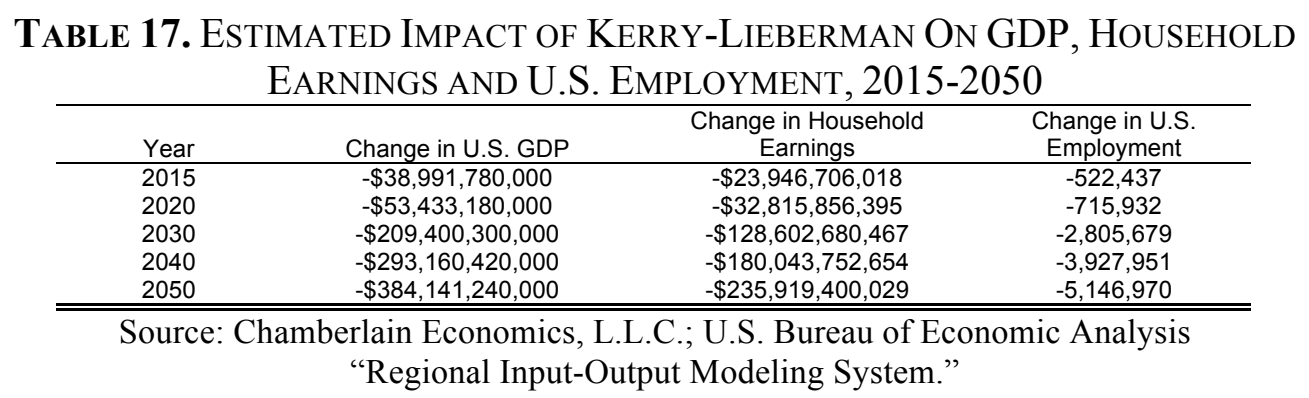

Table 17 provides estimates of the economic impact of Kerry-Lieberman on U.S. employment and household earnings between 2015 and 2050. Overall, the bill is expected to reduce employment by an estimated 522,000 jobs in 2015 , rising to more than 5.1 million job losses by 2050 compared to the EPA baseline of no cap-and-trade policy. In terms of reduced household earnings, the bill would reduce total wages earned by $\$ 23.9$ billion in 2015, rising to over $\$ 235.9$ billion in 2050 .

Figure 22 presents the data from Table 17 graphically. Based on EPA estimates, job losses from the Kerry-Lieberman bill are projected to be relatively modest in the early years of the program. However, as the Kerry-Lieberman bill's emissions cap declines sharply beyond 2020, the impact on GDP and employment grows rapidly. By the final year of the legislation, the bill is estimated to have displaced approximately 5.1 million workers compared to the EPA's baseline.

\footnotetext{
${ }^{45}$ See Bureau of Economic Analysis, "Regional Input-Output Modeling System (RIMS II)." Available online at www.bea.gov/regional/rims/.
} 
Figure 22. Estimated ReduCED U.S. EMPlOyMENT DUE to THE

KERRY-LIEBERMAN CAP-AND-TRADE BILL, 2015-2050

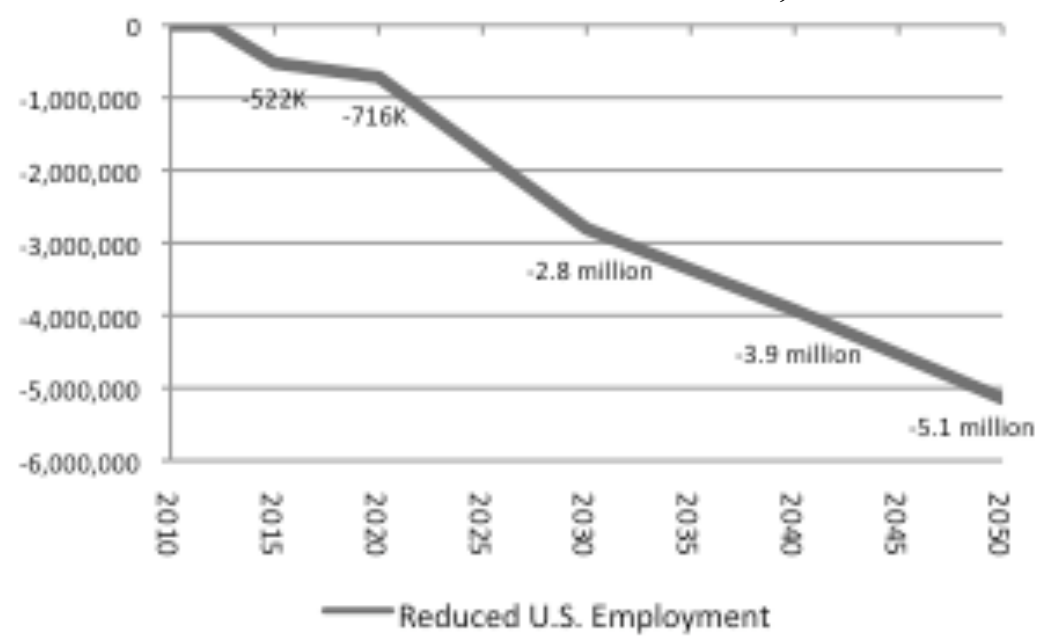

Source: Chamberlain Economics, L.L.C.; U.S. Bureau of Economic Analysis "Regional Input-Output Modeling System."

In Table 18, we present industry-by-industry estimates of the impact of Kerry-Lieberman on GDP, household earnings and employment in 2020. The figures are designed to illustrate the industry-level composition of the bill's employment and earnings effects in a given year, and represent a one-year snapshot of the bill's impact in the year 2020.

As price increases caused by cap-and-trade reduce the quantity of products demanded from various industries, carbon-intensive industries will tend to reduce output. This declining output will in turn lead to reduced demand for labor in these industries, ultimately reducing U.S. employment and household earnings. In Table 18, the reductions in GDP from the Kerry-Lieberman bill are estimated to fall most heavily on firms producing carbon-intensive goods such as petroleum and coal products; electric and natural gas utilities; chemical manufacturers; and farms. The three most heavily affected industries are petroleum and coal products with roughly 119,000 job losses; electric and natural gas utilities with 81,400 job losses; and chemical products with approximately 49,700 job losses.

Because of the large degree of uncertainty in the underlying data, some caution is warranted in interpreting the estimates in Table 18. These figures - as with all estimates based on RIMS II multipliers - should be considered order-of-magnitude approximations only, and do not represent precise estimates of the Kerry-Lieberman bill's impact on jobs and household earnings. 


\section{TABLE 18. ECONOMIC IMPACT OF KERRY-LIEBERMAN ON EMPLOYMENT AND}

HOUSEHOLD EARNINGS FOR VARIOUS U.S. INDUSTRIES, YEAR 2020

\begin{tabular}{|c|c|c|c|}
\hline \multirow[b]{2}{*}{ Industry } & \multicolumn{3}{|c|}{ Economic Impact of Reduced GDP from Kerry-Lieberman Bill (2020) } \\
\hline & Change in U.S. GDP & $\begin{array}{c}\text { Change in Household } \\
\text { Earnings }\end{array}$ & $\begin{array}{c}\text { Change in U.S. } \\
\text { Employment }\end{array}$ \\
\hline Farms & $-\$ 1,392,099,359$ & $-\$ 891,361,219$ & $-33,744$ \\
\hline Forestry, fishing, and related activities & $-\$ 191,569,369$ & $-\$ 180,745,700$ & $-6,327$ \\
\hline Oil and gas extraction & $-\$ 1,245,456,318$ & $-\$ 760,849,265$ & $-12,972$ \\
\hline Mining, except oil and gas & $-\$ 1,193,988,223$ & $-\$ 786,599,442$ & $-15,398$ \\
\hline Support activities for mining & $-\$ 20,520,831$ & $-\$ 12,523,863$ & -261 \\
\hline Utilities & $-\$ 9,632,727,155$ & $-\$ 4,464,769,036$ & $-81,428$ \\
\hline Construction & $-\$ 568,591,070$ & $-\$ 570,637,998$ & $-14,247$ \\
\hline Wood products & $-\$ 336,717,070$ & $-\$ 278,566,032$ & $-7,772$ \\
\hline Nonmetallic mineral products & $-\$ 772,290,826$ & $-\$ 591,265,856$ & $-13,236$ \\
\hline Primary metals & $-\$ 2,337,774,019$ & $-\$ 1,366,896,469$ & $-29,110$ \\
\hline Fabricated metal products & $-\$ 1,453,136,643$ & $-\$ 1,117,462,079$ & $-25,631$ \\
\hline Machinery & $-\$ 356,503,874$ & $-\$ 274,757,535$ & $-5,915$ \\
\hline Computer and electronic products & $-\$ 558,497,051$ & $-\$ 505,998,328$ & $-9,983$ \\
\hline Electrical equipment, appliances, and components & $-\$ 277,540,206$ & $-\$ 207,655,582$ & $-4,500$ \\
\hline Motor vehicles, bodies and trailers, and parts & $-\$ 942,942,921$ & $-\$ 717,956,740$ & $-15,474$ \\
\hline Other transportation equipment & $-\$ 150,655,015$ & $-\$ 123,989,077$ & $-2,437$ \\
\hline Furniture and related products & $-\$ 82,296,546$ & $-\$ 68,890,439$ & $-1,785$ \\
\hline Miscellaneous manufacturing & $-\$ 154,043,716$ & $-\$ 138,777,983$ & $-2,902$ \\
\hline Food and beverage and tobacco products & $-\$ 1,172,966,216$ & $-\$ 899,782,384$ & $-23,427$ \\
\hline Textile mills and textile product mills & $-\$ 414,335,183$ & $-\$ 335,901,533$ & $-8,329$ \\
\hline Apparel and leather and allied products & $-\$ 54,866,570$ & $-\$ 50,570,517$ & $-1,378$ \\
\hline Paper products & $-\$ 1,083,952,883$ & $-\$ 781,638,424$ & $-17,778$ \\
\hline Printing and related support activities & $-\$ 331,999,449$ & $-\$ 299,928,302$ & $-7,048$ \\
\hline Petroleum and coal products & $-\$ 14,977,896,297$ & $-\$ 6,801,462,708$ & $-118,972$ \\
\hline Chemical products & $-\$ 3,748,455,534$ & $-\$ 2,489,724,166$ & $-49,725$ \\
\hline Plastics and rubber products & $-\$ 1,048,157,542$ & $-\$ 745,659,275$ & $-17,037$ \\
\hline Wholesale trade & $-\$ 576,102,259$ & $-\$ 461,285,079$ & $-10,163$ \\
\hline Retail trade & $-\$ 208,569,184$ & $-\$ 171,485,583$ & $-5,533$ \\
\hline Air transportation & $-\$ 367,594,617$ & $-\$ 273,159,560$ & $-6,162$ \\
\hline Rail transportation & $-\$ 150,911,066$ & $-\$ 99,903,126$ & $-2,093$ \\
\hline Water transportation & $-\$ 16,129,193$ & $-\$ 11,864,635$ & -268 \\
\hline Truck transportation & $-\$ 938,912,777$ & $-\$ 846,054,304$ & $-21,263$ \\
\hline Transit and ground passenger transportation & $-\$ 82,039,506$ & $-\$ 81,120,664$ & $-3,012$ \\
\hline Pipeline transportation & $-\$ 442,136,162$ & $-\$ 262,319,385$ & $-5,274$ \\
\hline Other transportation and support activities & $-\$ 564,463,496$ & $-\$ 563,673,247$ & $-13,096$ \\
\hline Warehousing and storage & $-\$ 114,353,760$ & $-\$ 110,305,637$ & $-3,024$ \\
\hline Publishing industries (includes software) & $-\$ 173,759,709$ & $-\$ 135,723,709$ & $-2,993$ \\
\hline Motion picture and sound recording industries & $-\$ 40,867,567$ & $-\$ 33,065,949$ & -801 \\
\hline Broadcasting and telecommunications & $-\$ 410,539,602$ & $-\$ 257,408,330$ & $-5,593$ \\
\hline Information and data processing services & $-\$ 63,182,932$ & $-\$ 48,050,620$ & $-1,111$ \\
\hline Federal Reserve banks, credit intermediation, and related & $-\$ 249,911,577$ & $-\$ 154,445,354$ & $-3,304$ \\
\hline Securities, commodity contracts, and investments & $-\$ 128,226,639$ & $-\$ 145,049,974$ & $-2,808$ \\
\hline Insurance carriers and related activities & $-\$ 133,471,091$ & $-\$ 117,454,560$ & $-2,509$ \\
\hline Funds, trusts, and other financial vehicles & $-\$ 4,658,144$ & $-\$ 5,329,383$ & -103 \\
\hline Real estate & $-\$ 696,159,298$ & $-\$ 227,156,779$ & $-6,785$ \\
\hline Rental and leasing services and lessors of intangible assets & $-\$ 171,101,899$ & $-\$ 122,491,850$ & $-3,077$ \\
\hline Miscellaneous professional, scientific and technical services & $-\$ 857,354,646$ & $-\$ 880,503,221$ & $-19,297$ \\
\hline Management of companies and enterprises & $-\$ 435,225,939$ & $-\$ 416,598,269$ & $-8,093$ \\
\hline Administrative and support services & $-\$ 1,237,030,349$ & $-\$ 1,176,168,456$ & $-38,008$ \\
\hline Waste management and remediation services & $-\$ 102,125,937$ & $-\$ 79,719,506$ & $-1,876$ \\
\hline Educational services & $-\$ 60,548,556$ & $-\$ 62,534,549$ & $-1,986$ \\
\hline Ambulatory health care services & $-\$ 23,368,763$ & $-\$ 23,908,581$ & -554 \\
\hline Hospitals and nursing and residential care facilities & $-\$ 6,389,254$ & $-\$ 6,728,523$ & -174 \\
\hline Social assistance & $-\$ 3,494,051$ & $-\$ 3,533,883$ & -146 \\
\hline Performing arts, spectator sports, museums, and related & $-\$ 53,333,743$ & $-\$ 54,907,088$ & $-1,904$ \\
\hline Amusements, gambling, and recreation industries & $-\$ 18,617,291$ & $-\$ 14,743,033$ & -545 \\
\hline Accommodation & $-\$ 118,281,365$ & $-\$ 91,762,683$ & $-2,763$ \\
\hline Food services and drinking places & $-\$ 249,434,435$ & $-\$ 204,411,519$ & $-8,453$ \\
\hline Other services, except government & $-\$ 234,905,307$ & $-\$ 208,619,403$ & $-6,346$ \\
\hline Total & $-\$ 53,433,180,000$ & $-\$ 32,815,856,395$ & $-715,932$ \\
\hline
\end{tabular}

Note: Initial reductions in GDP are assumed to be proportional to fossil-fuel carbon intensity by industry. Source: Chamberlain Economics, L.L.C.; U.S. Bureau of Economic Analysis "Regional Input-Output Modeling System." 


\section{CONCLUSION}

The aim of the Kerry-Lieberman bill is to reduce U.S. greenhouse gas emissions in a way that shares the burden of climate policy equitably among households, with as little burden as possible on the U.S. economy. The legislation falls short of that goal in several ways.

One of the most basic criticisms of climate policy is its regressive impact on low-income households. Advocates have long argued that cap-and-trade can be made progressive through an appropriate distribution of free emission allowances to low-income households. While true in principle, in practice the Kerry-Lieberman bill does not follow this approach, instead distributing most allowances freely to companies, government agencies and others in an effort to secure political support for the bill's passage.

Between 2013 and 2030, the Kerry-Lieberman bill distributes nearly 80 percent of allowances freely, primarily to four U.S. industries: electricity local distribution, natural gas local distribution, "trade exposed" industries, and commercial carbon capture and sequestration. Over the life of the bill, shareholders in these four industries are granted an estimated $\$ 1.6$ trillion subsidy - equivalent to transferring roughly 1.5 times the annual revenue of the federal personal income tax directly to shareholders in these industries, ${ }^{46}$ many of which reside in the nation's highest income quintile.

Lawmakers' decision to grant most allowances freely to companies worsens the regressive impact of the bill. On a gross basis, the bill imposes a regressive burden ranging from 5.2 percent of income for low-income households to just 1.1 percent for households in top quintile. Even when all benefits to households are accounted for, the bill remains regressive with households in the bottom four quintiles paying an annual burden of between $\$ 157$ and $\$ 437$ per year while households in the top quintile financially benefit by $\$ 510$ per year. The bill effectively redistributes approximately $\$ 12.3$ billion per year to share-owning households in the nation's top quintile.

In terms of the bill's broader economic impact, using EPA estimates of the bill's effect on GDP we find the bill would reduce U.S. employment by roughly 522,000 in 2015 , rising to 5.1 million job losses by 2050 .

Aside from the distributional impact of the bill, Kerry-Lieberman suffers from serious flaws in its policy design. The bill's exclusion of petroleum refiners from quarterly auctions - a provision designed to shield refiners from price volatility - is instead likely to have the opposite effect, increasing volatility faced by covered entities with no obvious economic or environmental benefit.

As debate over climate policy continues in the U.S. Senate, lawmakers should reflect on these flawed aspects of the Kerry-Lieberman bill and consider ways of addressing the problems identified in this study.

\footnotetext{
${ }^{46}$ See U.S. Office of Management and Budget, supra note 31.
} 


\section{Methodology ANd Data Sources}

The distributional estimates in Section III are based on a Leontief input-output model developed by Chamberlain Economics, L.L.C. to simulate the economic impact of various climate policies on U.S. households. The model simulates the production relationships among 133 U.S. industries and households, comparing consumer prices both with and without cap-and-trade based on the following equations,

(1) Consumer Prices w/o Kerry-Lieberman (Commodity Level): $P_{c}=Z^{\prime} \cdot\left(I-A^{\prime}\right)^{-1} \cdot V$

(2) Consumer Prices w/ Kerry-Lieberman (Commodity Level): $\hat{P}_{c}=Z^{\prime} \cdot\left(I-A^{\prime} \cdot T\right)^{-1} \cdot V$

where $V$ is an $n \times 1$ vector of each industry's value added, $\left(I-A^{\prime} \cdot T\right)^{-1}$ is the Leontief inverse matrix, $T$ is an $n \times n$ matrix with $(1+$ industry effective burden from the KerryLieberman bill $t$ ) along the diagonal and zeros elsewhere, and $Z$ is an $n x m$ price transformation matrix that converts industry-level burdens into commodity-level price impacts. The data for the model are drawn from the 2002 benchmark input-output accounts from the U.S. Bureau of Economic Analysis, and incorporate 2008 consumer expenditure and other data from the Consumer Expenditure Survey (CEX) from the U.S. Bureau of Labor Statistics. ${ }^{47}$

\section{InCidence Assumptions for Allowance Values}

Estimates of net household burdens in Section III require assumptions about the economic incidence of various provisions in the bill that return allowance values to households. Table 19 presents a list of provisions returning benefits to households and the assumed economic incidence and statistical allocators for each. The 2020 value of provisions is based on the quantity of allowances allocated to each program and an estimated 2020 allowance price based on a mid-point of the upper and lower bounds of the allowance price collar established by the bill. The 2020 value of allowances was inflation-adjusted to 2008 dollars using a long-term Consumer Price Index forecast from Conway Pedersen Economics, Inc. These benefits were then distributed to households based on the statistical allocators listed in Table 19.

\section{IMPACT ON EMPLOYMENT AND EARNINGS}

The economic impact estimates presented in Section V are based on 2006 RIMS II multipliers from the U.S. Bureau of Economic Analysis. The multipliers are "Type II" multipliers that account for the impact of both industry and household purchases. EPA estimates of the Kerry-Lieberman bill's reductions in GDP for various years were distributed to individual industries based on Chamberlain Economics, L.L.C.'s fossil-fuel carbon intensities for U.S. industries. ${ }^{48}$ These reductions in industry GDP were then multiplied by RIMS II final-demand multipliers, yielding industry-by-industry estimates of reduced employment and household earnings.

\footnotetext{
${ }^{47}$ For the complete input-output model methodology, see Chamberlain (2009).

${ }^{48}$ Chamberlain Economics, L.L.C.'s estimates of fossil-fuel carbon intensity for U.S. industries and products are available at www.chamberlaineconomics.com/data/.
} 


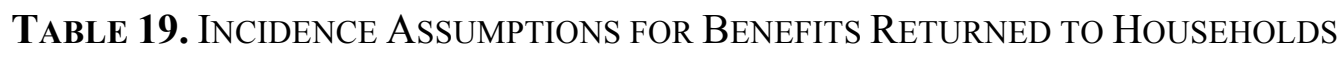
FROM FREE ALLOWANCES IN THE KERRY-LIEBERMAN BILL

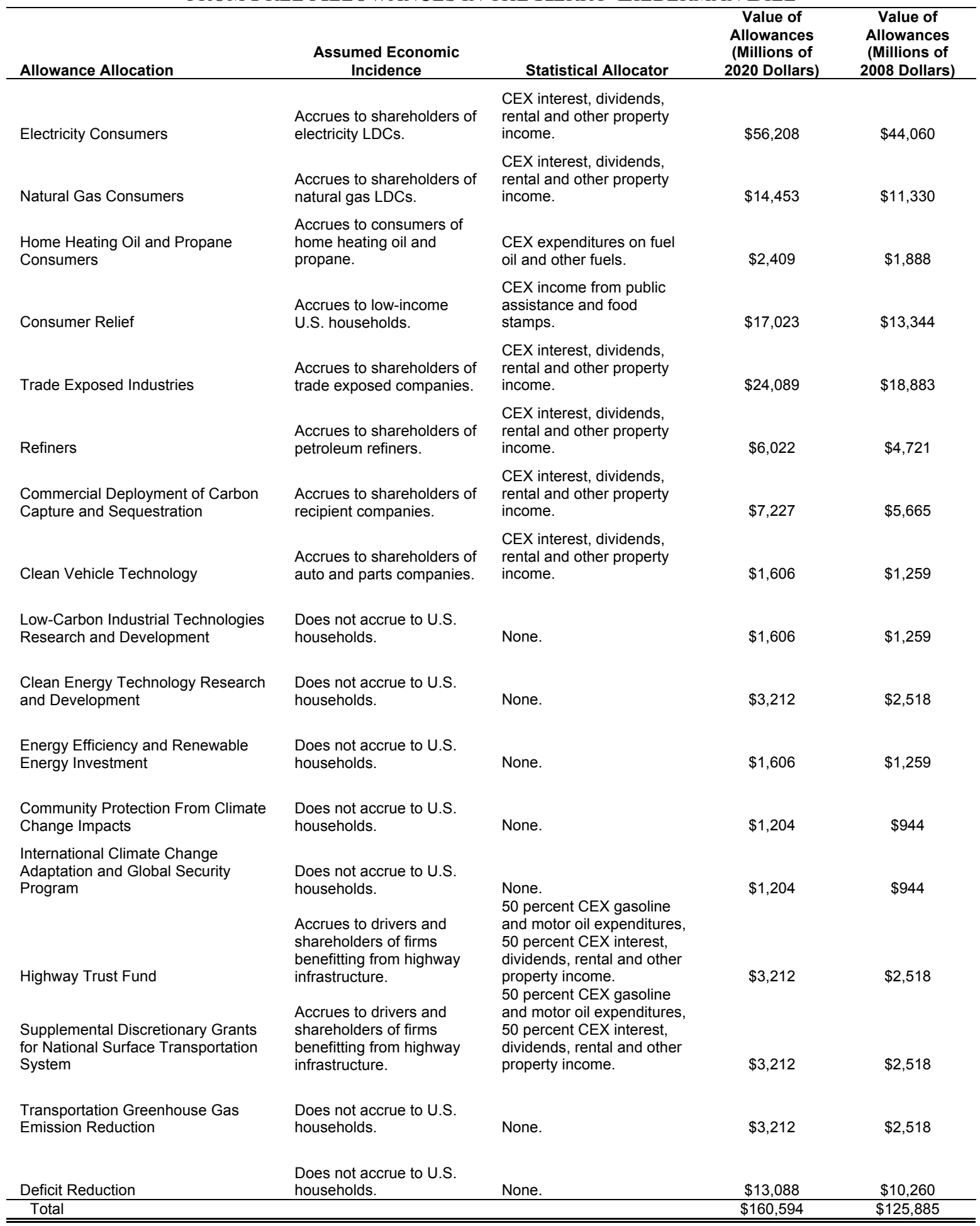

Source: Chamberlain Economics, L.L.C. 


\section{Appendix. Detail on Auction Price Volatility}

In this section we provide additional mathematical detail underlying the analysis in Section II of how the Kerry-Lieberman bill's exclusion of petroleum refiners from quarterly auctions may affect price volatility over time. ${ }^{49}$

Suppose regulators were able to perfectly forecast the number of allowances required by refiners each period. In this case, it can be shown by a simple numerical example that the bill's auction procedure will be identical to an ordinary auction. ${ }^{50}$ Allowance prices will be the same under either system, and the bill would achieve its goal of shielding refiners from volatility.

Instead, suppose more realistically that regulators do not forecast perfectly. Like all forecasters, regulators will typically set aside too few or too many allowances each quarter. In this case, it can be shown that the bill's auction procedure will lead to one of three distinct outcomes: (1) price convergence over time; (2) price divergence; or (3) price oscillation.

To see why, consider the path of allowance prices and quantities over time. In the first period, suppose regulators authorize a total of $A$ emission allowances, setting aside $C_{l}$ for refiners. They then auction $\left(A-C_{l}\right)$ allowances to non-refiners, which yields an auction price $P_{1}$. At this price, refiners choose their emissions for the period and demand $Q R_{1}$ allowances, which may be greater than or less than $C_{l}$. Regulators' forecast error for the first period is then $\varepsilon_{l}=Q R_{l}-C_{l}$. If too many allowances were set aside, $\varepsilon_{l}<0$, indicating the next forecast should be smaller. If too few were set aside, $\varepsilon_{l}>0$, indicating the next guess should be larger.

In the next period, regulators correct their forecast using information about actual demand last period. Suppose regulators correct their forecast using last period's error, setting aside $C_{2}=C_{1}+\varepsilon_{1}$ allowances for refiners. Since $\varepsilon_{1}=Q R_{1}-C_{1}$, then $C_{2}=C_{1}+$ $\left(Q R_{I}-C_{I}\right)$, or $C_{2}=Q R_{I}$. Thus, in the absence of perfect knowledge of industry demand for allowances, regulators' best forecast for refiner demand this period is the observed quantity demanded by refiners last period.

This process repeats in every subsequent period: a forecast by regulators, an auction to non-refiners, a choice of quantity by refiners, and a corrected forecast. Viewed in this

\footnotetext{
${ }^{49}$ Although we consider only the case of linear demand functions, they may be considered first-order Taylor approximations of actual (possibly non-linear) demand functions in the neighborhood of the bill's allowance quantities and prices.

${ }^{50}$ Under Kerry-Lieberman, suppose regulators distribute 100 emission allowances per quarter. Suppose refiner demand for allowances is $R(P)=100-2 P$, with $P$ as the allowance price, and let non-refiner demand be $D(P)=100-P$. Suppose regulators set aside 33 allowances for refiners. The auction price for the remaining 66 will be $\$ 33$ and refiners will demand exactly 33 - a perfect forecast by regulators. Now consider the same scenario under an ordinary auction. The total demand for allowances would be the sum of refiner and non-refiner demand, or $R(P)+D(P)=200-3 P$. If 100 allowances are sold at auction, the price will be $\$ 33$ - the same as under the Kerry-Lieberman system.
} 
way, the Kerry-Lieberman bill generates a series of prices $p_{1}, p_{2}, p_{3} \ldots=\left\{p_{n}\right\}_{n=1}^{\infty}$ as regulators search for the correct number of allowances to set aside for refiners. This series will either converge or diverge. If it converges, the system will approach the "correct" equilibrium allowance price over time. If it diverges, it will either "blow up" with prices swinging further outward over time, or oscillate around the equilibrium allowance price.

The general result can be stated simply: allowance prices converge under KerryLieberman if and only if refiner demand for emission allowances is less price elastic than non-refiner demand. If refiner demand is more elastic than non-refiner demand, prices diverge. If refiners and non-refiners have identical demand functions, prices oscillate.

This can be seen in Figures 23, 24 and 25, which illustrate the three cases. Figure 23 illustrates price convergence, while Figure 24 illustrates divergence and Figure 25 illustrates price oscillation.

In the figures, non-refiner demand for allowances is labeled $D(P)$, and refiner demand is labeled $R(P)$. The bottom axis shows non-refiner's quantity of allowances, while the top axis shows refiner quantity. Thus, $D(P)$ is drawn in the normal downward-sloping way, while $R(P)$ is flipped and is related to the top axis. By drawing the curves in this way, the non-refiner quantities on the bottom axis are always equal to the total number of allowances minus the refiner quantities on the top axis-a convenient way of emphasizing that all allowances must be divided in some way between refiners and nonrefiners. The total number of allowances each quarter is labeled $A$, and regulators initial forecast of allowances for refiners is $c_{1}$. The progression of the system over time is labeled 1, 2, 3 and so on in each figure.

Figure 23. Price Convergence: Refiner Demand for Allowances is LESS Elastic THAN NON-REFiner DEMAND

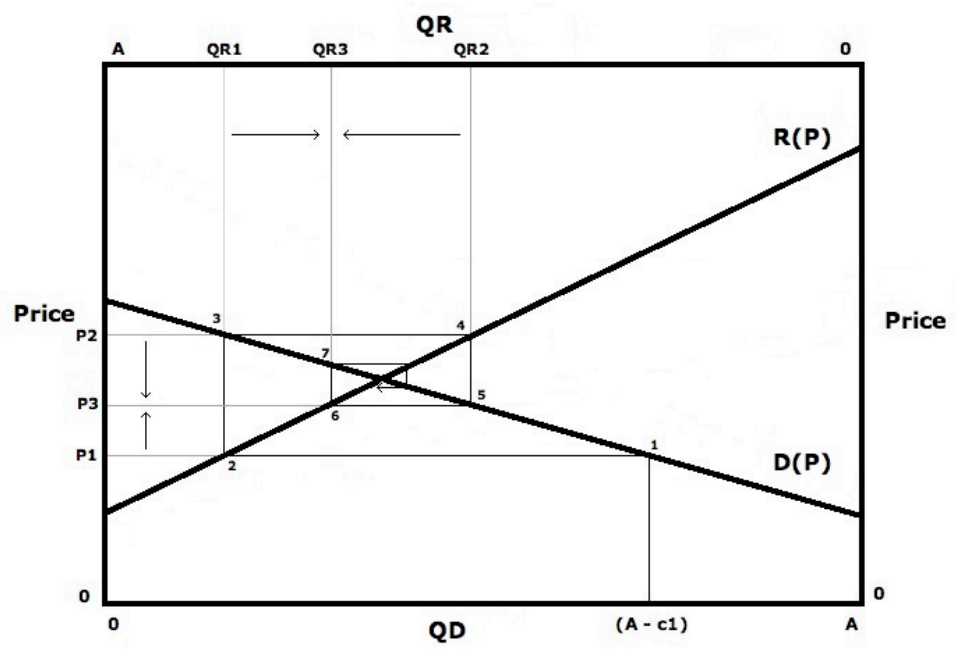

Source: Chamberlain Economics, L.L.C. 
Figure 24. Price Divergence: Refiner Demand for Allowances IS MORE ELASTIC THAN NON-REFINER DEMAND

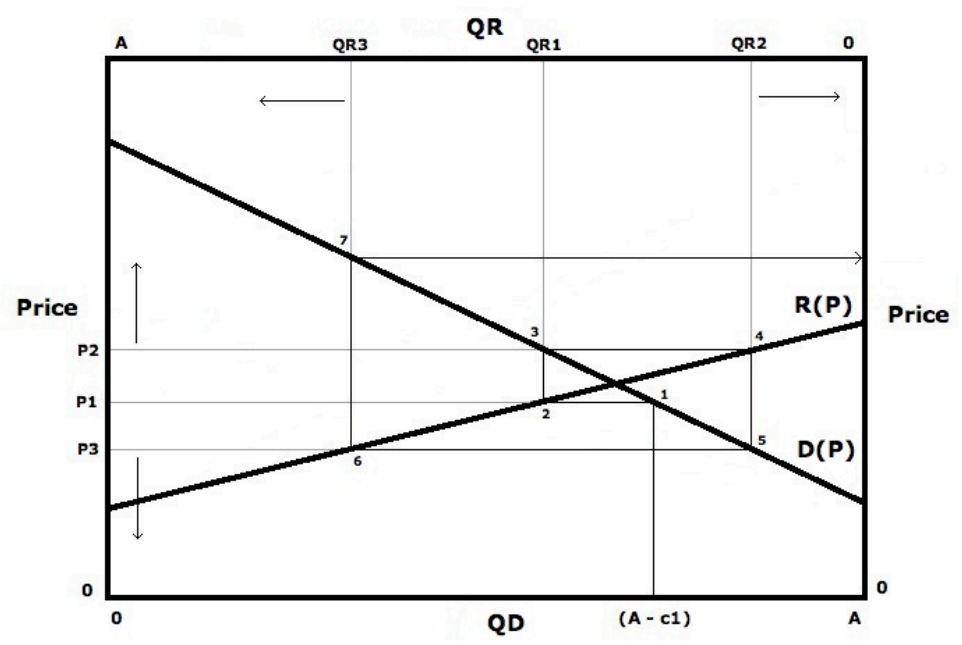

Source: Chamberlain Economics, L.L.C.

Figure 25. Price Oscillation: Refiners and Non-Refiners HaVe IDENTICAL DEMAND CURVES For AllowanCES

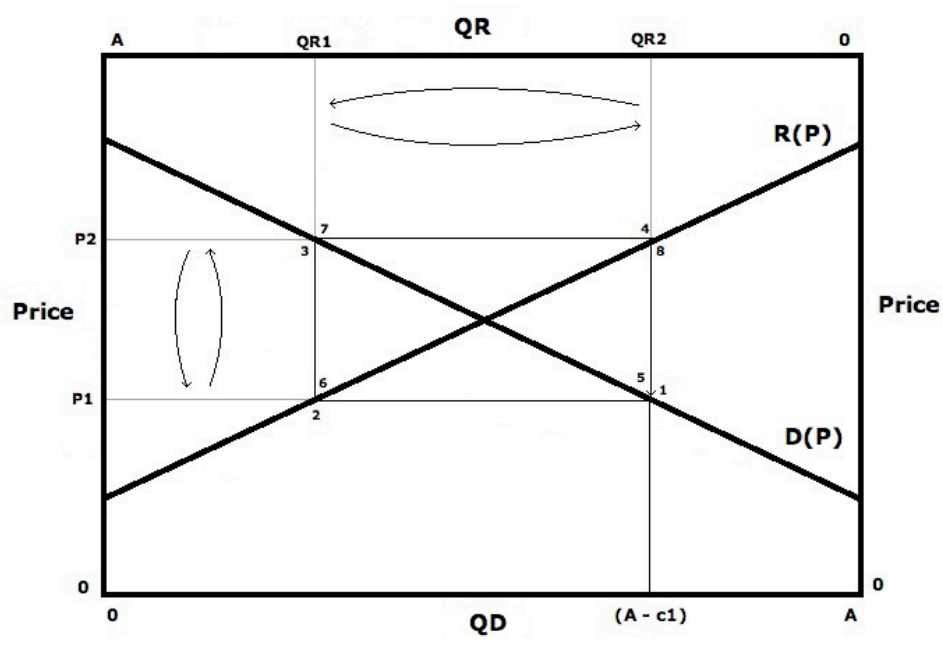

Source: Chamberlain Economics, L.L.C.

\section{Empirically Calibrating Demand Curves}

Using econometric estimates of industry price elasticities for greenhouse gas emissions from Bataille and Jaccard (2007), it is possible to empirically calibrate industry demand curves as in the above figures to simulate the impact of Kerry-Lieberman on allowance price volatility over time.

From Bataille and Jaccard, allowance price elasticities for refiners and non-refiners are 0.73 and -0.51 , respectively. In 2013, the Kerry-Lieberman bill authorizes 4,651 million allowances to covered industries, or 1,163 million per quarter at a forecasted allowance 
price of $\$ 20 .^{51}$ Refiners account for 43 percent of covered emission under the bill, so a reasonable estimate of the number of allowances they would require is $(0.43) \times(1,163)$ or roughly 500 allowances. The remaining 663 are left to non-refiners.

Based on these parameters, we estimate the following linear functions for refiner and non-refiner demand for emission allowances (in millions of allowances) in 2013:

(1) Refiners: $R(P)=865.00-18.25 P$

(2) Non-Refiners: $D(P)=1000.35-16.87 P$

These estimated demand functions are plotted in Figure 26 following the graphical conventions of the diagrams above. In the figure, the "ideal" regulator forecast of QR = 500 is marked by arrows at the intersection of the two demand curves. This forecast would leave 663 allowances to non-refiners, resulting in an auction price of $\$ 20$. For regulator forecasts greater or less than 500, prices quickly diverge from the equilibrium, leading to continually larger forecast errors over time.

Figure 26. ECONOMETRICALly CALIBRATEd REFINER AND Non-REFiner DEMAND Functions For Allowance Under KERRY-LIEBERMAN, YeAr 2013

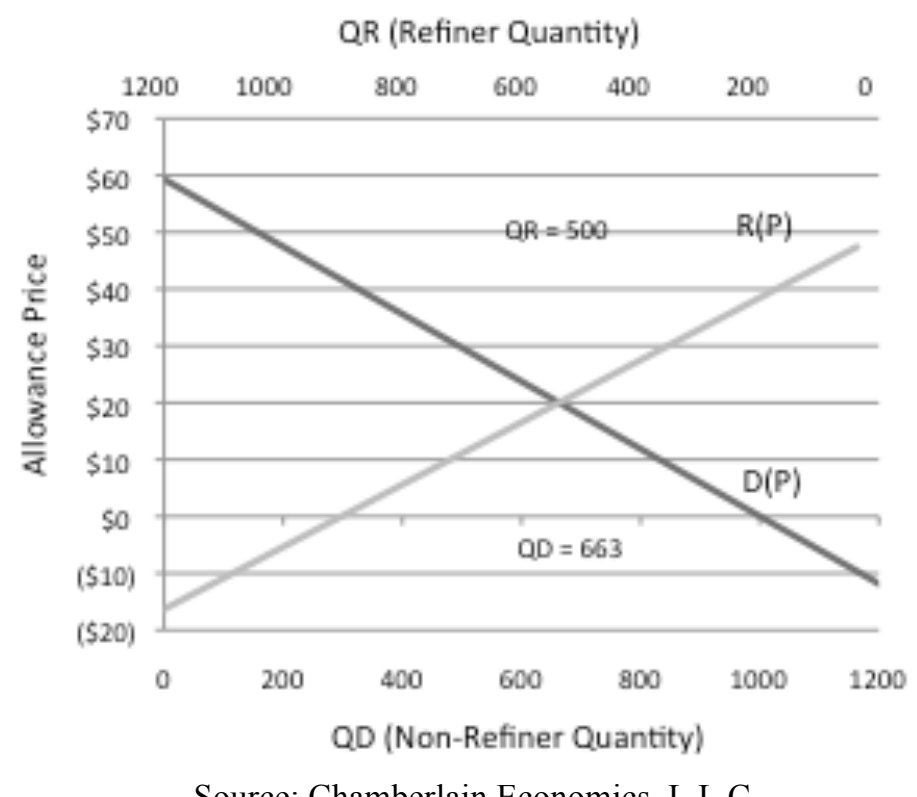

Source: Chamberlain Economics, L.L.C.

To illustrate the issue of price volatility under the Kerry-Lieberman bill, an Excel-based simulation model is available from the authors upon request. The model allows users to input parameters for refiner and non-refiners demand, and view the impact on price convergence, divergence and oscillation over time. Requests may be submitted via email to andrew@chamberlaineconomics.com.

\footnotetext{
${ }^{51}$ For simplicity we ignore the impact of freely distributed allowances to industries in this illustration.
} 


\section{REFERENCES}

Armington, Paul (1969). "A Theory of Demand for Products Distinguished by Place of Production," International Monetary Fund Staff Papers 16.

Bataille, Chris and Mark Jaccard. (2007). "Greenhouse Gas and Energy Price Elasticities Using a Hybrid Top-Down, Bottom-Up Model,” draft paper under review. Available at www.rds.oeb.gov.on.ca/webdrawer/webdrawer.dll/webdrawer/rec/83743/view/.

Burtraw, Dallas et al. (2009). "Distributional Impacts of Carbon Pricing Policies in the Electricity Sector," Resources for the Future Discussion Paper 09-43. Available at www.rff.org/documents/RFF-DP-09-43.pdf.

California Department of Finance. (2010). "General Funds, Bond Funds and Special Funds Total," Chart B: Historical Data-Budget Expenditures. Available at dof.ca.gov/budgeting/budget_faqs/documents/CHART-B.pdf.

Center for Continuing Study of the California Economy. (2009). "2008 California Economy Rankings," Numbers in the News August 2009. Available at www.ccsce.com/Numbersnews.php.

Chamberlain, Andrew and Feliz M. Ventura. (2010). "Industry Profits, Stock Prices and Household Burdens: A Distributional Analysis of the Kerry-Boxer Cap-and-Trade Bill," Chamberlain Economics Policy Study No. 2010-03. Available at http://papers.ssrn.com/sol3/papers.cfm?abstract_id $=1605455$.

Chamberlain, Andrew. (2009). "Who Pays for Climate Policy? New Estimates of the Household Burden and Economic Impact of a U.S. Cap-and-Trade System," Tax Foundation Working Paper No. 6. Available at www.taxfoundation.org/files/wp6.pdf.

Chamberlain, Andrew and Gerald Prante. (2007). "Who Pays Taxes and Who Receives Government Spending? An Analysis of Federal, State and Local Tax and Spending Distributions, 1991-2004," Tax Foundation Working Paper No. 1. Available at www.taxfoundation.org/files/wp1.pdf.

Conway Pedersen Economics, Inc. (2009). "History and Ten Year Forecast" (December 2009). Available at www.economicforecaster.com.

Corbett B. Daly, "Lawmakers Slam Top Mortgage Firms on Loan Mods," Reuters (June 24, 2010). Available at www.reuters.com/article/idUSN2419665720100624.

Fullerton, Don. (1995). "Why Have Separate Environmental Taxes?” NBER Working No. Paper W5380. Available at www.nber.org/papers/w5380. 
Goulder, Lawrence. (2002). "Mitigating the Adverse Impacts of CO2 Abatement Policies on Energy-Intensive Industries," Resources for the Future Discussion Paper 02-22. Available at www.rff.org/documents/RFF-DP-02-22.pdf.

Government Finance Officers Association. (2001).“GFOA Recommended Practice: Setting of Government Charges and Fees." Available online at www.gfoa.org/downloads/rpCCIsettingofgovernmentchargesfees2001.pdf.

Huber, Peter W. (2008). "The Million-Volt Answer to Oil," Energy Policy and the Environment Report (October 2008). Center for Energy Policy and the Environment at the Manhattan Institute. Available at www.manhattan-institute.org/pdf/eper_03.pdf.

International Monetary Fund. (2010). "IMF Reaches Staff-level Agreement with Greece on $€ 30$ Billion Stand-By Arrangement," Press Release No. 10/176 (May 2, 2010). Available at www.imf.org/external/np/sec/pr/2010/pr10176.htm.

Kanter, James and Jad Mouawad. (2008). "Money and Lobbyists Hurt European Efforts to Curb Gases." New York Times (December 11, 2008). Available at www.nytimes.com/2008/12/11/business/worldbusiness/11 carbon.html.

Lavelle, Marianne. (2009). "The Climate Change Lobby Explosion," The Center for Public Integrity, (February 24, 2009). Website article. Available at www.publicintegrity.org/investigations/climate_change/articles/entry/1171/.

Leonnig, Carol D. (2008). "Effectiveness of AIG's \$143 Billion Rescue Questioned," Washington Post (November 3, 2008). Available at washingtonpost.com/wpdyn/content/article/2008/11/02/AR2008110202150.html.

Metcalf, Gilbert. (1999). “A Distributional Analysis of Green Tax Reforms.” National Tax Journal, Volume LII, No. 4.

Mikesell, John L. (2007). "Gross Receipts Taxes in State Government Finances: A Review of Their History and Performance," Tax Foundation Background Paper No. 53. Available at www.taxfoundation.org/files/bp53.pdf.

National Energy Technology Laboratory. (2010). "Carbon Sequestration FAQ Information Portal." Available at netl.doe.gov/technologies/carbon_seq/FAQs/techstatus.html.

Office of Sen. John Kerry. (2010). "Addressing Transportation and Refined Products," Website article. Available at www.kerry.senate.gov/imo/media/doc/transpolpage.pdf.

Rausch, Sebastian et al. (2010). "Distributional Implications of Alternative U.S. Greenhouse Gas Control Measures," NBER Working Paper No. 16053. Available at www.nber.org/papers/w16053. 
Stigler, George J. and Claire Friedland. (1962). "What Can Regulators Regulate? The Case of Electricity," Journal of Law and Economics (October 1962).

Stigler, George J. (1971). "The Theory of Economic Regulation," The Bell Journal of Economics and Management Science, (Spring 1971).

U.S. Bureau of Labor Statistics. (2008). "Consumer Expenditure Survey.” Available at www.bls.gov/cex/.

U.S. Bureau of the Public Debt. (2010). "Total Public Debt Outstanding." Website article. Available at www.publicdebt.treas.gov.

U.S. Energy Information Administration. (2007). "Federal Financial Interventions and Subsidies in Energy Markets 2007." Available at www.eia.doe.gov/oiaf/servicerpt/subsidy2/pdf/chap1.pdf.

U.S. Census Bureau. (2010). "U.S. Trade Balance with China: 2009," Foreign Trade Statistics. Available at www.census.gov/foreign-trade/balance/c5700.html.

U.S. Congress. (2009). H.R. 2454, “American Clean Energy and Security Act of 2009." Available at www.hdl.loc.gov/loc.uscongress/legislation.111hr2454.

U.S. Congressional Budget Office. (2009). "The Economic Effects of Legislation to Reduce Greenhouse-Gas Emissions." CBO Publication No. 4001. Available at www.cbo.gov/doc.cfm?index=10573.

U.S. Department of Health and Human Services. (2010). "National Health Expenditures Web Tables 1960-2008," Centers for Medicare and Medicaid Services. Available at www.cms.gov/NationalHealthExpendData/downloads/tables.pdf.

U.S. Environmental Protection Agency. (2010). "Inventory of U.S. Greenhouse Gas Emissions and Sinks: 1990-2008.” USEPA No. 430-R-10-006. Available at www.epa.gov/climatechange/emissions/usinventoryreport.html.

U.S. Environmental Protection Agency. (2010). "EPA Analysis of the American Power Act in the 111th Congress, Appendix." (June 14, 2010). Available at www.epa.gov/climatechange/economics/pdfs/EPA_APA_Analysis_Appendix_6-1410.pdf.

U.S. Office of Management and Budget. (2010). "Budget Summary Tables for Fiscal Year 2011." Available at www.whitehouse.gov/omb/budget/fy2011/assets/tables.pdf.

Viard, Alan D. (May 4, 2009). "Don't Give Away the Cap-and-Trade Permits!" Tax Notes. Available at www.aei.org/article/100451. 